\title{
Race Classification at the University of KwaZulu-Natal: Purposes, Sites and Practices
}

IOLS-Research, Dr Shaun Ruggunan and ccrri

For:

Centre for Critical Research on Race and Identity (ccrri)

2010 


\section{Table of Contents}

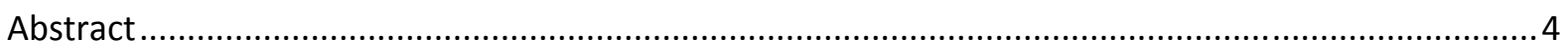

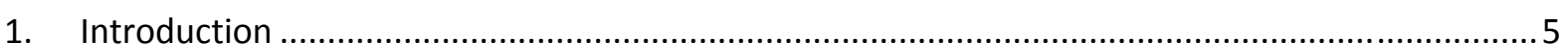

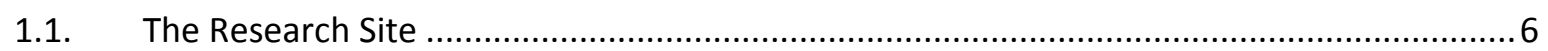

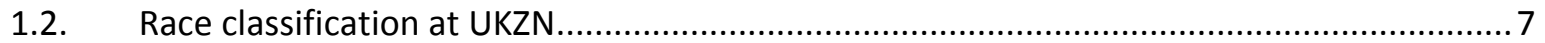

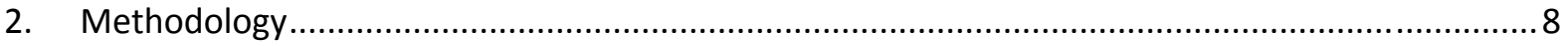

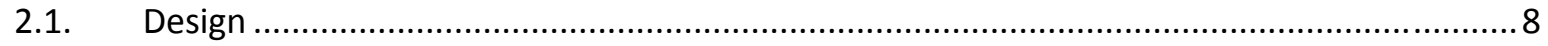

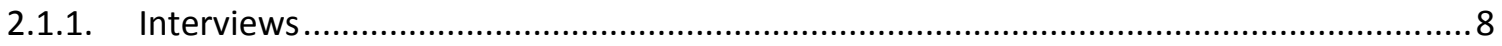

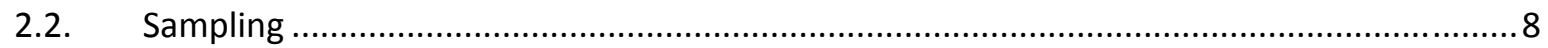

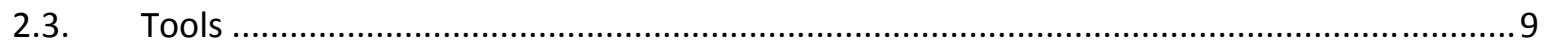

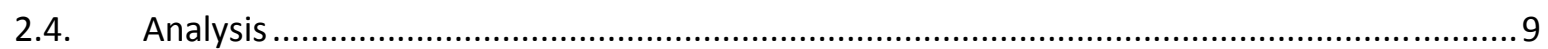

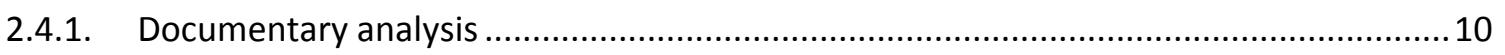

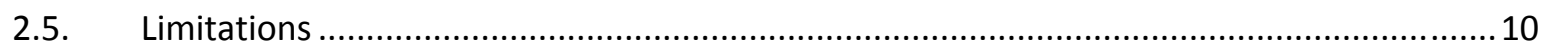

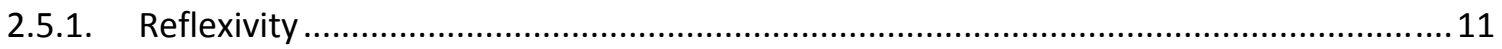

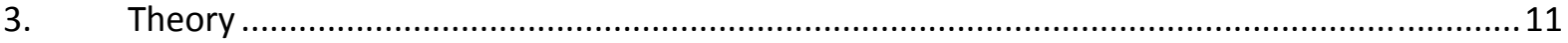

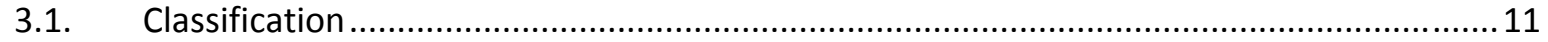

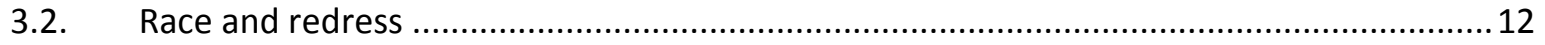

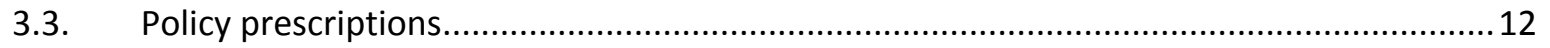

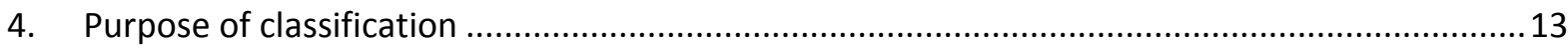

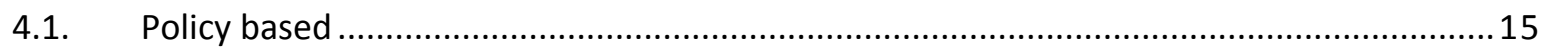

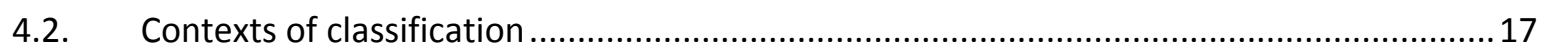

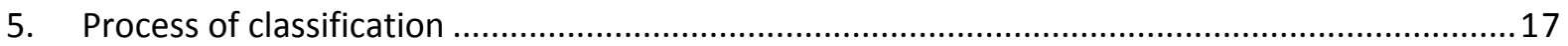

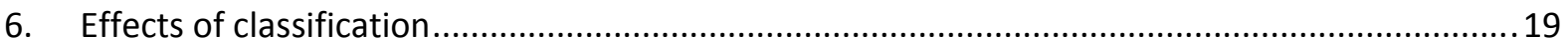

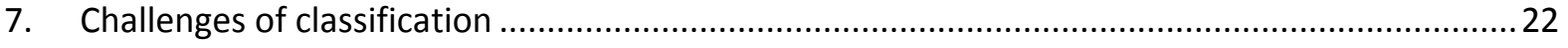

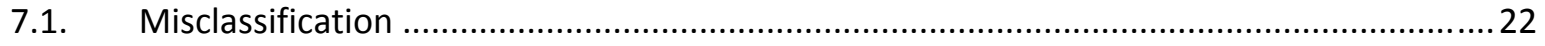

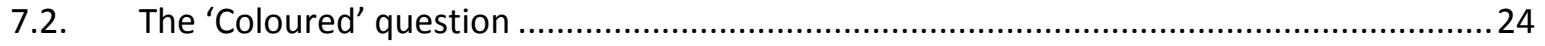

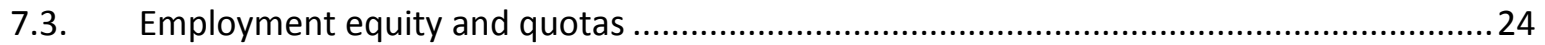

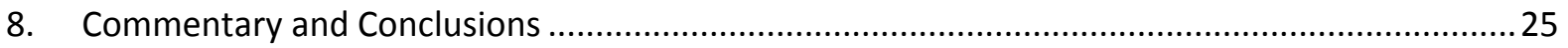

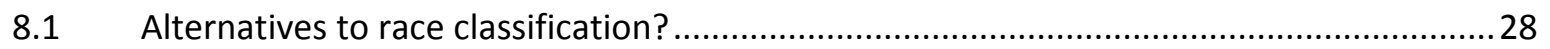

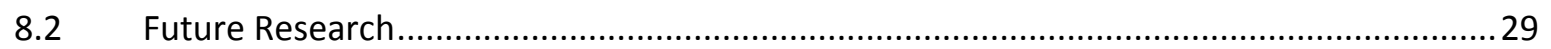

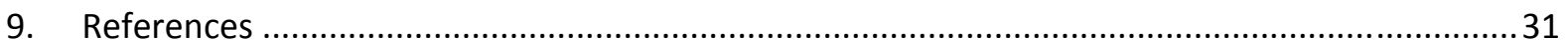

Appendix 1: Some forms requiring race classification (attached) ......................................................... 34

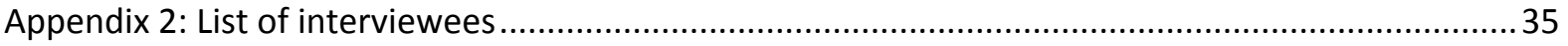


Appendix 3: Interview schedule (2009)

.36

Appendix 4: UKZN Equity Plan for the Division of Student Services 2006 (Extract) ...

.37 


\begin{abstract}
Race classification has long been a feature of South African life, in daily life and its cognitive processes, and also in formal state-driven bureaucratic forms. In the post-apartheid period, classification of individuals on the basis of race has continued despite a stated commitment to principles of non-racialism. Primarily, this is justified in its formal manifestation because of the acknowledged need for redress of apartheid generated inequalities both in the labour market and in access to opportunities and resources (such as higher education).
\end{abstract}

Investigating the purposes and practices of race classification in an institution of higher learning in South Africa - in this case, the University of KwaZulu-Natal as one of the largest employers in the province of KwaZulu-Natal, as well as one of the largest national universities - offers a particularly interesting insight into these issues and provides an example of sites where this occurs. The research project has three key aims. Firstly it seeks broadly to identify the purpose of race classification, secondly the project investigates the processes followed in classifying people according to race, thirdly the study is interested in the effects, if any, of both classifying and being classified (from the perspective of the classifier) and the challenges involved in race classification. The project concludes by suggesting alternatives to race based classification. 


\section{Introduction}

Classifying people by race has long been a feature of South African life. Under apartheid, the Population Registration Act (30 of 1950) was the major legislative tool determining the institutionalised procedures that underpinned the process of race classification. The Act classified people into racial categories according to criteria that could best be described as 'a deliberately more flexible, elastic approach...' (Posel, 2001a: 55). Its effects were often damaging to the individuals concerned, given the subjective nature of classifying people racially. This subjective nature of racial classification raises the credibility of racial classification (in addition to questions of morality and dignity as argued by Eloff [1999]).

In the post-apartheid period, classification of individuals on the basis of race has continued despite a stated commitment to principles of non-racialism. ${ }^{1}$ While race classification has had continuity in everyday practice, it also remained (such as in the Census) and has increasingly become re-institutionalised, albeit in a different form in post-apartheid South Africa. The processes through, and reasons for which this occurs are often unclear. Policy - either nationally derived or developed by individual institutions - often drives the process, the reasons for, and implementation of, such classification, but can be subjective and context dependent. Primarily, such policy is most often justified because of the acknowledged need for redress of apartheid generated inequalities both in the labour market and in access to opportunities and resources (such as higher education).

Generally, classification processes are undertaken by individuals at lower levels in the organisational hierarchy to whom responsibility for doing so has been devolved, often as a default requirement rather than as a formal job description. ${ }^{2}$ These individuals may have differing interpretations of policy requirements and may attach different weight to the implications of the processes and practices of classification itself. On the other side of the practice are the individuals being classified, and their own subjective experiences of the process/es involved. While this is equally, if not more important, as a field of inquiry, this latter question was beyond the scope of the pilot study reported on here. ${ }^{3}$

\footnotetext{
${ }^{1}$ This commitment is made primarily in the Constitution of the Republic of South Africa (Act 108 of 1996) where it states explicitly under the Founding Provisions of Chapter 1 in subsection 1 that "The Republic of South Africa is one, sovereign, democratic state founded on the following values: ...(b) Non-racialism and nonsexism."

${ }^{2}$ Erasmus, Y (2007) discusses how responsibility for classifying and reclassifying people under apartheid was devolved to lower level bureaucrats.

${ }^{3}$ However, see Erasmus, Y (2007) where the effects of undergoing processes of reclassification under apartheid legislation are explored.
} 
Higher education institutions in South Africa offer a particularly fascinating institutional space in which to examine the processes of race classification. Here both employees and 'clients' (students) are routinely classified, for the stated purpose of fulfilling national government legislative and policy requirements and the individual institutions' own professed goals.

Moreover, the widely reported occurrence of racial humiliation at a residence at the University of the Free State in 2008 has triggered renewed focus and attention on 'race', racism and racial discrimination in the South African higher education sphere. The incident in question made global and national headlines. The intense focus on racism particularly at universities provided a new impetus to debates on race and racism in higher education. The government initiated Ministerial Committee on 'Transformation, Elimination of Discrimination and Social Cohesion in Public Higher Education Institutions', which generated a report on its findings in late 2008, is an example of this concern (South Africa, 2008). Two key findings of this Committee were, firstly, that discrimination is perceived to be rife in Higher Education Institutions; and, secondly, that in many institutions policies of transformation and organisational cultures are in conflict. In the context of this report, higher education institutional space and the ways in which its officials engage with 'race' classification becomes even more interesting.

\subsection{The Research Site}

The University of KwaZulu-Natal (UKZN) was born out of a merger in 2004 between the Universities of Natal and of Durban-Westville. The merger process was driven by national government plans to restructure and reconfigure the higher education landscape in South Africa, in order to derive benefits of greater efficiency resulting from economies of scale, as well as redress historical imbalances between former privileged and formerly disadvantaged institutions. It must be noted that while ostensibly the new UKZN was the result of a merger between two previously separate institutions to form a new entity in which neither took precedence, the larger size and relative financial stability (among other factors) of the University of Natal over the University of Durban-Westville, meant that the merger was often seen as more of a takeover by the former institution than a merger of equals. This perception has informed many decisions and interpretations of conflicts during the ongoing process. 
The merger process, which resulted in a large scale restructuring of the joint organisation, was not particularly smooth. ${ }^{4}$ The underlying tensions and stresses of bringing together two distinct organisational cultures have simmered below the surface, sometimes in racialised form. However solidarity amongst most academic and support staff emerged in 2007, when industrial action took place, with UKZN staff protesting to achieve higher wage increments. The 2007 industrial action was a moment of solidarity that transcended race, hierarchy and loyalties to the former institutions of UN or UDW.

\subsection{Race classification at UKZN}

While discussions of race in South Africa often take on normative overtones, they are also often portrayed in sensationalist terms. The purpose of this research report is to take a more considered approach to analysing the experience of race classification from the perspective of the classifier. It does this by moving beyond the experience of racism through which race is most often discussed and analysed in South Africa, to the supposedly 'common sense' processes and practices involved in the everyday experience of filling in forms and classifying people into various racial categories. The research project seeks broadly to identify the purpose of race classification; the processes followed in classifying people according to race; the effects, if any, of both classifying and being classified (although the latter was investigated here only as a perception held by the classifier); and the challenges involved in race classification. Lastly, possible alternatives to classification on the basis of race are tentatively probed. The structure of the report that follows is therefore built around these themes. To begin, however, it is necessary to outline the methodology followed in undertaking this project.

\footnotetext{
${ }^{4}$ For views of the merger process and achievements from the management involved in the merger process, see Makgoba and Mubangizi (eds) (2010).
} 


\section{Methodology}

\subsection{Design}

The research made use of qualitative methodologies. The primary method employed was that of semi-structured interviews with key informants. This methodology was supported by a brief analysis of a sample of documents or forms at UKZN which require individuals to classify themselves in terms of pre-defined racial categories.

\subsubsection{Interviews}

Key informants were selected to provide primary data on the core research questions. Initially, potential gatekeepers and interviewees were contacted via email in order to request either an interview with themselves or with their subordinates who were tasked with classifying individuals on the basis of race. If there was no response to the initial email then this was followed up with further emails and phone calls until a response was elicited. In the case of a positive response, an interview was scheduled and an email was sent as a confirmation to the interviewee.

Two sets of interviews were conducted and used. The first set of four interviews was conducted in 2002 and the second set in 2009. The 2002 interviews were conducted with senior human resource managers at the former University of Natal, the former University of Durban-Westville, the former Natal Technikon, and the former M.L Sultan Technikon.

In both cases interviews were conducted either face to face or over the telephone and lasted between 15 minutes and an hour. The vast difference in time can be explained by the fact that some interviewees had little substantive information to provide as they did not engage in classification processes themselves and therefore could not respond meaningfully to some of the questions on the interview schedule.

All interviews were recorded using a digital recorder and this was supplemented by notes taken by the interviewer.

\subsection{Sampling}

A combination of targeted and snowball sampling was used to identify the key informants to be interviewed in 2009. Initially, departments or units within UKZN that the researchers 
believed undertook race classification were identified and heads of these departments were contacted to gain permission to conduct interviews either with themselves or their subordinates or both. Finally 15 interviews were conducted with 13 key informants. ${ }^{5}$ The 2002 interviews were conducted with the senior human resources practitioners, as indicated above, and no sampling took place.

The 2009 interviews were conducted with people from various units within the university including Division of Management Information (DMI), Student Funding and Scholarships, Human Resources and Equity, NTESU (a staff union), International Relations, Engineering Faculty, Humanities Faculty, Student Affairs, and Risk Management Services. In addition personal correspondence took place with a representative from the National Research Foundation (NRF) in June 2010. Unless otherwise indicated this Report refers to the 2009 interviews and results, pertaining to UKZN.

\subsection{Tools}

The primary research tool employed in both sets of interviews was a semi-structured interview schedule that was used to frame the interview. ${ }^{6}$ While the researchers generally followed the interview schedule in structuring the discussion, the semi-structured format allowed for probing and digressions where these were deemed appropriate. It also gave the researchers the freedom to allow the interview to develop organically with the interviewee sometimes taking the lead and addressing issues that s/he felt were pertinent.

\subsection{Analysis}

Given the small sample size, interviews were transcribed and then analysed manually (i.e. without the use of qualitative analysis software). The data was broken down according to what were identified by the researchers as the main themes; namely:

- The purpose of classification;

- The process of classification;

- The effects of classification;

- The challenges of classification; and

- Alternatives to race classification.

\footnotetext{
${ }^{5}$ See Appendix Two.

${ }^{6}$ See Appendix Three.
} 
These themes also broadly inform the structure of this report.

\subsubsection{Documentary analysis}

In addition to the interviews, a selection of official university documents, including application forms for both undergraduate and postgraduate study, the Emma Smith scholarship, and fixed term appointments, were identified and gathered from various sources at UKZN where individuals (both staff and students) are asked to classify themselves into one of four race categories - 'African', 'White', 'Indian’ or 'Coloured'. ${ }^{7}$ A fifth category, 'Other' is available in the case of the university application forms and, more recently, 'Foreigner' in the case of the appointment form. The scholarship form which was looked at does not request information on race; rather, under 'Heritage', it offers a choice between 'British' and 'Dutch'. This particular scholarship is of interest as a result of a recent case which successfully sought a variation to the Emma Smith Education Fund in terms of 'the deletion of clause 26 (f) (2) of the words "European”, "British” and "or Dutch South African”, ${ }^{8}$ Further research into the case, its judgement and consequences is necessary, as well as its relationship to the scholarship forms in circulation.

\subsection{Limitations}

The research was limited primarily by the lack of a positive, timeous response from some of the key informants identified as essential to the study. For example, Human Resources is one of the main departments responsible for classifying individuals at UKZN, especially of employees at the University. However, the researchers were unable to schedule an interview with any of the personnel identified from this Department in the time allocated for primary data collection. An interview was conducted with an individual from the Deputy Vice Chancellor's Office responsible for Human Resources and Equity at the University; however, he himself was not directly involved in processes of classification.

\footnotetext{
${ }^{7}$ See Appendix One.

${ }^{8}$ University of Kwazulu-Natal v Makgoba and Others (17124/2005) [2009] ZAKZDHC 28. p. 2. This case was taken to the Supreme Court of Appeal and, 11 years after it started, resolved in favour of what is now the University of KwaZulu-Natal. The award is now open to all women living in Durban. An irony, in the light of the Report here, is that one of the arguments advanced by the University was that the fund, established in 1938, in its present context 'flew in the face of the institution's non-racial policies, as well as what was a radically transformed South Africa' (Weekend Witness, October 2, 2010).
} 
In general the interview process proceeded slowly due to key informants' busy schedules. For example, interviews with individuals from Student Affairs, Student Housing, the Scholarships Officer and the Finance Officer were postponed a number of times and in some cases could not take place at all.

\subsubsection{Reflexivity}

In the context of South Africa with its apartheid past, asking questions about 'race' seems immediately to put people on the defensive or at least make them wary with regard to the intentions of the researcher. As a result, the interviews were conducted in a relatively 'active' manner (Holstein and Gubrium, 2004) with a great deal of probing and even some directing of the discussion into areas that the interviewers felt were of greater interest than what interviewees were offering. In some cases, potentially contradictory information (to what was being stated) elicited in previous interviews was put forward in order to gather responses.

\section{Theory}

\subsection{Classification}

Classification of people into discrete categories is a tool used by modern states to enable them better to understand and manage the complexities of their societies (Christopher, 2009; Nobles, 2000). The most wide-ranging tool that the state uses to classify people is the census and categories may include gender, age, nationality, home language and/or language proficiency, religion, and race among others. These categories are generally also used in other areas of the state bureaucracy, including registrations of births and deaths and applications for identity or travel documents. From this sphere, the categories created can be and often are adopted by other organisations and individuals or groups of individuals, especially when the categories (and variables within these) used take on the mantle of common sense as arguably, has been the case in South Africa with regard to race (Posel, 2001b; Maré, 2001). As Scott argues (Scott, 1998 cited in Christopher, 2009: 102) demonstrates, classification of human beings into categories, particularly racial, can have profound consequences for their experience of the human condition:

'The categories that may have begun as the artificial inventions of cadastral surveyors, census takers, judges or police officers can end by becoming categories that organize people's daily experience precisely because they are embedded in statecreated institutions that structure that experience'.

In other words the sometimes arbitrary classification of people makes real or reifies their imposed classification; it shapes as much as it represents. Such is the power of the classifier. It is important to note in this regard that these are socially constructed categories that are often politically determined and derived out of a specific historical and cultural context that is 
nevertheless always in flux. The categories and classifications therefore are constantly subjected to production and negotiation in response to changing circumstances, while themselves contributing to determining those circumstances (Burr, 1995; Ramji, 2009; Maré 2001).

\subsection{Race and redress}

In South Africa, widespread classification on the basis of race took place in 1865 in the census conducted in that year by the colonial Cape government. This classification (with some variations) was then subsequently used periodically in censuses conducted in the region up to the present day (Christopher, 2009). As Christopher (2009) points out, however, in certain years (1890 in the South African Republic, 1918, 1926, 1931 and 1941 in the Union of South Africa) only white people were counted in the census because of the need to delineate constituencies for racially selective elections.

Race based classification was consolidated into four possible variables during the latter period of the Union of South Africa and entrenched under apartheid (Christopher, 2009). In the post-apartheid period these four variables are still used although it is currently adopted in order to 'judge the effectiveness of measures of redress' (Maré, 2001: 81). It is of concern, however, that this classificatory scheme is adopted in a way that suggests that it is unproblematic, without discussion and debate and in a way that contributes to the 'everyday banality of race classification’ in South Africa (Maré, 2001: 82; Posel, 2001b).

\subsection{Policy prescriptions}

Measures of redress in South Africa are prescribed in government policy and given weight through legislative prescriptions, primarily the Employment Equity Act (55 of 1998) (South Africa, 1998a) and the Broad-Based Black Economic Empowerment Act (53 of 2003) (South Africa, 2003). ${ }^{9}$ Both these Acts necessitate the classification of individuals on the basis of race in order to ensure compliance and to measure progress towards race-based redress. Furthermore, non-legislated policy prescriptions from the national Department of Education also mandate higher education institutions, for example, to undertake classification on the basis of race under their reporting requirements in order to measure redress in provision of higher education.

In other countries, classification takes place on the basis of race using different variables, and in some cases race based classification can be disguised as classification on the basis of population group, nationality, lineage, or ethnicity. In many of these countries, this

\footnotetext{
${ }^{9}$ This Act aims to change the ownership structure of the South African economy away from predominantly white hands.
} 
classification is undertaken in order to measure what may be perceived as a problematic 'other', usually minority, group (Van der Haar and Yanow, 2009; Yanow and Van der Haar, 2009). The next section examines the need for and purpose of classifications in South African work organisations, particularly universities. The section provides a context for the bureaucratic project of classification before shifting into a more theoretical discussion on diversity and social identity in the workplace.

\section{Purpose of classification}

Since the advent of democracy in 1994, measures of redress adopted by the South African government included legislation such as the Employment Equity Act, the Skills Development Act (97 of 1998) (South Africa, 1998b) and Broad-Based Black Economic Empowerment Act. The effects of these measures and of the abolition of previous discriminatory legislation and practices have in the past few years seen the movement of designated groups into occupational levels from which they were historically barred, creating a racedemographically diverse workforce on different levels (Moleke, 2003). Accompanying this has been a growing discourse on race, race classification, and what constitutes diversity and diversity management, which not only featured prominently in government (Bunn, 2008:2) and corporate circles (Human, Bluen and Davies, 1999) but also in the intellectual community whereby, amongst others, the challenges and potential benefits of workplace diversity and its effective management received great attention (Mbigi and Maree, 1995; Beall, 1997; Maré, 2001, Human, 2005).

Advocates of legislated racial redress argue that 15 years after South Africa's first democratic elections, prejudice and stereotyping are still alive and well in the South African workplace, where discrimination, exclusion and intolerance of diversity take on subtle undertones in organisational culture rather than being overt. Discrimination it would appear is institutionalised both formally and informally in rigid, traditionalist organisational cultures such as universities, especially those classified as formerly white universities (South Africa 2008: 131-136).

Classification on the basis of race is understood as being necessary in order to achieve racial redress and transformation in South African society generally and in higher education specifically. In this regard, classification has become important as a human resources practice in South African workplaces. In this sense the UKZN is a workplace, within which human 
resource practitioners have to engage in the practice of classification on a daily basis to achieve specified goals. In such sites, classification of employees in racial categories permeates the work requirements of many human resource practitioners, especially those involved in recruitment, selection, promotion and retention of staff.

The 2002 series of interviews with senior human resource practitioners at tertiary institutions in KZN, namely, the former institutions Natal Technikon, M.L. Sultan Technikon, University of Natal and University of Durban-Westville, demonstrated that institutional policy in regard to the purpose of classification was very clear to those interviewed: to redress racial inequity and fulfil the national legislated mandate to achieve employment equity.

Whilst there was some acknowledgement of the more philosophical and even pragmatic problems involved in classifying human beings racially, these were seen as more of an exception than any reason to question the logic for the continuation of racial classification of South Africans in a post-apartheid scenario. For practitioners, those employees who refused to accept their classification or actively sought to change their classification from one race to another were 'strange', 'eccentric' and 'anti-transformation', 'mischievous' and 'troublesome'. For example as Reena Budree, former equity manager at the University of Natal claimed in 2002:

....and so racial classification at the university is totally self defined. You define what race you belong to and if you came to me and said you're a white woman, I would have to accept that...the university would never challenge a person... It was a kind of atmosphere that prevailed at the time, in 1999, where they still felt that if you were resistant to enough to this piece of legislation it would go away, but it [the legislation] didn't go away. And so the kind of mischievous behaviour that we had, fortunately went away because we said that's fine, but in future in all university publications or any publicity material derived from the university, you would in fact be reflected as an African female [if that was the classification you claimed] (Interview Budree, 2002).

For Budree, employees who embarked on this form of self classification at the former University of Natal, did so as a form of protest. However, the action of refusing to self classify is often interpreted as a form of refusing to 'give up racial privilege'. All such claims of bizarre classification actions as a means of protest by individuals against the universities' implementation of racial classification policy, if accurate, would remain speculation here.

Hope Mashilo (Interview, 2002), the Equity Manager at the former M.L. Sultan Technikon, also provides examples when employees wished to reclassify themselves racially. Mashilo elaborates on one incident where the institution's classification policy was challenged by staff. In 2000 three 'Muslim Indians', she said, approached her insisting that they be 
reclassified as Coloured or Cape Malay as they did not consider themselves Indian. She refused to reclassify them on the basis that their original identity books used when first applying for their jobs in the 1980s classified them as Indian. She argues that the only motivation for them wanting to be reclassified as Coloured or Cape Malay was that it would ensure them access to a range of resources and rights that they would not be able to access if they retained their Indian classification. The specifics of the rights and resources were not mentioned in the interview, but one can speculate that it might have referred to occupational mobility within the Technikon.

Mashilo's argument demonstrates the reductiveness of classifying others or indeed of self classification. She further contends that if these employees were accepted for employment at the Technikon in the 1980s then they had to be 'real Indians' and not 'Coloured or Cape Malays or whatever' (Interview Mashilo, 2002) since the Technikon was an 'Indian only' institution during this period and would only employ Indians.

The manager in charge of equity at the former Durban University of Technology, Lizwi Mhlane, alerted the researcher to the balancing act that he had to perform between what he terms the philosophy of equity and the pragmatics of equity. He contends that whilst he acknowledges the difficulties in classifying people or forcing them to classify themselves he nonetheless supports racial classification when he argues that:

Its more of a philosophical thing than a real thing. Like I say the exigencies of the institution make it almost impossible for people to start hiding things like that [their race] (Interview Mhlane, 2002).

Mhlane goes on to argue that for him racial classification is grounded in what he perceives to be reality. Reality for him in this context means achieving measurable racial redress within the institution.

The four senior HR managers interviewed in 2002 all acknowledged that there may be large philosophical issues around processes of classification, but also believe that employees can be classified. Their job was not to do the 'philosophy' but the work of classification to achieve national and institutional mandates.

\subsection{Policy based}

Interviewees in the UKZN (2009) study all agreed that classification on the basis of race at the university is practised in order to fulfil policy and/or legislative requirements. As stated previously, the primary policy tool determining the use of race classification for employees at 
UKZN is the Employment Equity Act. UKZN is required to take steps to ensure that its staff complement reflects the broader demographic profile of the province in terms of race, as well as gender and disability. ${ }^{10}$ It does this by devolving responsibility to line function departments in that the various departments/units/schools are required to develop their own divisional equity plans, keeping in mind the University’s Recruitment and Selection Policy. ${ }^{11}$

For students, the policies that are understood to drive race classification differ according to the context or situation in which it is deemed to be necessary. In general, all students are expected to be classified according to race during the application process and subsequently, once the application is successful, this classification is confirmed during the registration process. This is seen to be necessary in order to meet Higher Education SA (HESA) requirements says the Central Applications Office (Interview van Soelen et al, 2009) for transforming higher education institutions in South Africa, as well as UKZN's own institution wide Equity Plan.

In addition students are classified when they request financial assistance or are considered for awards like bursaries and scholarships in line with policies of, inter alia, UKZN, the National Student Financial Aid Scheme, the Leadership and Equity Advancement Programme (LEAP - important in the University's transformation initiative), and the various private and public scholarship and bursary programmes available. ${ }^{12}$ Funding for financial aid is understood to be determined largely by the racialised allocation of funding, as is alluded to in the following quote:

... we don't issue funding on the basis of race classifications, so that's not a criteria for getting funding but in order for us to receive funding from the state we need to report on students using their race classifications because that's part of the format currently (Interview Wills, 2009).

Therefore, at least in the opinion of the respondent cited above, the university itself does not feel compelled to fund students based on their racial classification. However, in order to secure the funding in the first place, the university has to provide race based statistics of its student body to the relevant government agencies. This signifies a second theme that emerges in the fieldwork undertaken for this study, namely the pressure by the state on the university, through legislation and a range of potential punitive measures for non-compliance, to engage in racial, as opposed to non-racial, discourse and practice.

\footnotetext{
${ }^{10}$ According to Statistics South Africa, the population group estimates for KwaZulu-Natal are as follows: African: 8002 407, Coloured: 141 887, Indian: 798 275, White: 483 448. Accessed on 30 January 2010 from: http://mapserver2.statssa.gov.za/GeographyWebsite/index.html

${ }^{11}$ For example, the UKZN Equity Plan for the Division of Student Services 2006. See extract in Appendix Four.

${ }^{12}$ For example, The General Entrant Equity Scholarship, the Prestige Entrant Scholarship, and the Emma Smith Bursary (Interview Naidoo, 2009)
} 


\subsection{Contexts of classification}

Race classification at UKZN occurs in many situations in which individuals, both staff and students, are required to engage with the bureaucratic management processes in place. In the case of staff, race classification begins at the recruitment stage, is established formally (by being 'captured on the system') once an individual is appointed, and is confirmed at subsequent interactions through ongoing processes of self classification (see below). In addition, staff may be required to classify themselves on the basis of race when joining a trade union. For example

... you're not bound to declare your race group but then if you don't in a sense you prejudice yourself in the employment process (Interview Govender, 2009).

Increasingly there is no space in South African work organisations not to be racially classified. It may be that the function to classify employees racially is primarily that of Diversity offices, Equity offices and allied human resources services. Where employees refuse to self-classify or challenge classification they are assigned a classification by human resources. Every column in the required reports has to be completed with the options already designated.

\section{Process of classification}

Classification is generally seen to occur through self-classification, or pre-classification as apartheid designations will have been carried into post-1994 systems. In other words, individuals (both employees and students) classify themselves or had been classified into one of the race categories available on the various forms they are required to fill in. In most cases, interviewees felt that classifying others is a largely unproblematic process. Respondents did not consider what other proof may be required to verify a person's race, if the classification was 'problematic'. The interpretation by the classifier of the process of racially classifying another person as unproblematic is telling. It reveals that racial classification is a normative, ordinary and even a banal process in contemporary South Africa. However, the process of classifying by the classifier is also an act of subjective power, and subjective reflection. Whilst it may be true that in some cases the classifier is not conscious of the power dynamic in classifying another human being racially, such a dynamic is nonetheless present. Removing the banality, the apparent common sense, of the process also forces the classifier to take accountability of the act of classifying. 
The main stumbling block to the process relying solely on self-classification is that while the application form (for students) contains an 'other' category (requiring specification), the database used to store student information requires that all students be categorised into the available variables thereby effectively excluding 'other'. This is the same process in effect used by the census (Erasmus and Stone, 2009): where an individual adds a value that is not recognised, this has to be absorbed into one of the accepted variables. According to the interviewees responsible for this database, in general where this emerges is with people identifying themselves either ethnically (e.g. Zulu) or nationally (in the case of foreign students) (Interview Van Soelen et al, 2009). This problem of what is in effect 'mis(self)classification' is then solved by first, reclassifying ethnic categories into racial ones (Zulu becomes African). Second, if that is unclear, then other available data is consulted, such as, firstly, the student's name and surname, followed by residential address, school, South African identity document, passport. Or confirmation may be based on face-to-face interaction (phenotype, visual, in other words). For example, a student did not wish to be classified as coloured and instead entered 'biracial' in the other field. The student was then called in to enable reclassification into one of the available categories. As the quote below demonstrates, the process of classifying can be alarmingly subjective.

... the lady said she was bi-racial what she meant was not coloured. She was not black-white she was in fact Indian and coloured, so she called herself bi-racial. Well there is a gap I mean if coloured is meant to be a black-white mix what is an Indian mix in any combination? [...] we then checked the school she was in, the address and the names ... even the names gave it away (Interview Van Soelen et al, 2009).

She was classified as 'Coloured' eventually, on the basis of her name, residential area and school, which were all seen as fitting the Coloured category. Names, or surnames more specifically, are considered to be a reliable indicator of race, as Kebeje (Interview, 2009) emphasised. However, when probed, he acknowledged that this was not always the case and that a surname could be misleading as an indicator of race:

... sometimes we just look at the surname. Like now when I see Govender, I think it's obvious that should be an Indian student.

$\mathrm{Q}$ ? Or could be coloured?

Ja and even now there are blacks that are under Govender. I have seen it now.

$\mathrm{Q}$ ? So now surname is not even appropriate?

Ja, it’s not appropriate now (Interview Kebeje, 2009).

In the Medical School, where race classification determines access, as a result of the quotabased policy in place, ${ }^{13}$

\footnotetext{
${ }^{13}$ According to Sturm (Interview, 2009) "We aim at 69\% black African students, 19\% Indian, 9\% coloureds and 3\% white".
} 
at the time of enrolment the staff and the undergraduate administration office checks the declared race against the student name and if there is any doubt the student is asked whether the information is correct or not (Interview Sturm, 2009).

Institution-wide practice is that, in general, any reclassification and corrections of errors in classification happens at Faculty level. This is mainly because this is a common site of student interaction with the University's administration. As stated:

The faculty holds biographical details in the system, they are the custodians of the detail so it would have to go back to them for reclassification (Interview Morrison, 2009).

According to some interviewees (Morrison, 2009; Naidoo, 2009) the student database or ITS system is not completely reliable, as there are sometimes cases of apparent 'misclassification' on the basis of both race and gender:

... we had a meeting the other day about data quality and at the end of the day, university systems need to be quality driven and then if the data sitting in them is incorrect then it's causing all sorts of problems to everybody (Interview Morrison, 2009).

In general, however, the processes of classification in the post-apartheid period have moved away from the more humiliating practices, such as the pencil test, that were sometimes carried out during apartheid (Erasmus, 2009).

\section{Effects of classification}

As noted in the introduction, the effects of apartheid era race classification were often devastating to the individuals concerned. Under the current democratic dispensation race classification, according to most of the interviewees (the classifiers), is not considered to be a major cause for concern. The 'everyday banality of race classification’ (Maré, 2001:82) that has permeated almost every aspect of public life in South Africa has meant that requests for race based classification are deemed most often to be unproblematic. Most people seem to accept the need for race classification in order to meet government's reporting requirements and the practice is seen as relatively unthreatening by work organisations, the human resources practitioners at tertiary institutions interviewed here, and by the state itself.

The non threatening and ordinariness in which classification is viewed by classifiers in work organisations is echoed in the interview excerpts below. One of the respondents, Trevor Wills (Interview, 2009) justifies the classification process by rendering it non-threatening. He 
asserts that there is no significant, if any, impact on the classified. Interviewees comment on this issue:

...I don't think it's a major problem because most of our students are local students and ... you grow up with these groups... (Interview Van Soelen et al, 2009).

But on the other hand very few people in my experience resist providing the information. So if they see it as something that appears to be a statutory requirement they generally seem to provide it whereas I would think 15 years ago more people would have simply not answered the question or left the section blank in a form or put some kind of comment down. People are resigned and provide it now because they will see it as being linked to some kind reporting requirement rather than any attempt to discriminate against the staff (Interview Wills, 2009).

You see I suspect that for a large part of South African society, I mean even the new generation, we are so used to doing the classification thing because once you went into post-classification you met the whole equity situation and so to keep yourself aligned for the equity (Interview Morrison, 2009).

At the same time however, the negative effects of classification for both the classified and classifiers are apparent as both Wills and Govender below point out:

... where this is discussed with staff for example in the context of employment equity, meetings or debates or contestation around employment equity there's a definite tension. You know I personally find it very difficult with having to use these classifications for example in interaction with staff meetings and strategic planning [...] where there's a need to refer to these categories and its usually couched in an apologetic tone to put it that way because there certainly is a sensitivity. And in KZN it's often very difficult, you can't use the old visual identification, names ... there's such an intermingling of names and speeches and so on its quite easy [...] to misclassify somebody (Interview Wills, 2009).

It has an effect on both sides, for the people making the classification you know, you're being called upon to sort of play this unique role again and labelling people and then all [...] that goes with these labels you know you become responsible for that. And you're the person sort of enforcing some kind of rule or regulation which would contradict a non-racial sort of discourse. On the side of the classified it can do different things [...] it can promote that racial category, that group in the labour market or whichever area or space that person is entering so you could raise them or you could label them as sometimes victims [...] of the past or you could label them using these racial epithets of being underprivileged (Interview Govender, 2009).

During apartheid, as Erasmus (2007) points out, where the effects of classification were often traumatic for individuals and families, those tasked with classifying individuals according to race were enormously powerful, despite the fact that they were often lower level bureaucrats. Bureaucrats still bear the responsibility for classification, in cases where self-classification does not work. But decision-making and recording, once again devolved to lower levels in any organisation, is now required as part of occupations far removed from any job- 
description (Maré, 2001). The processes have been sanitised, removed from the label of 'race-classification'. Processes adopted can still be highly subjective, or even more so. The effects of classification, on both the classifier and classified can be pronounced, with those responsible for classifying unable to fall back on specific criteria for doing so and, in addition, there may be a sense of general discomfort with classification on the basis of race given the recent past. This is especially the case where race classification is tied to access to resources (such as student funding) or employment as the excerpts from an interview with Morrison (Interview, 2009) demonstrates:

We did have a white student recently who came in and felt that because of the equity programmes of the National Research Foundation he was being disadvantaged and hadn't got funding. He was very angry with a black staff member and I intervened and told him that number one, it's not the black staff member who had actually been involved in the selection process, it was actually a government agency number one; and number two that he hadn't qualified for the funding that he thought he was eligible for not solely on race but basically based on his academic profile. His academic profile wasn't strong enough. The government agency said look, in terms of the equity profile only a certain number were for white males. He was a white male [...] had he been sufficiently strong enough academically the university may well have found an alternative scholarship, but he really just wasn't at the scholarship level. But he felt that he was being disadvantaged based on racial classification and gender classification. So you know that was an unfortunate situation

$[\ldots]$

When approached for comment [the communication was via personal email correspondence in June 2010], the NRF, confirmed that whilst some of their student scholarships are targeted at designated groups, in practice white males who apply and meet the merit conditions of the scholarship are granted the scholarship. The same 'leeway' applies to certain staff funding grants such as Thuthuka that are targeted at designated groups. The NRF argues that if not enough quality applications are received in a particular funding cycle, the particular scholarship or grant can be opened to white males. This depends often on the discretion of the NRF fund manager and not the individual university, even though this is eventually communicated to the relevant institutions.

Morrison (Interview, 2009) discussed the individual feeling of discomfit of employees when challenged by individuals who contest their classification or the process and purpose of classification:

I mean the biggest challenge is just an uncomfortableness on the part of the staff member who has to arrive at some kind of end result. And it's not our money that we are administering number one, and clearly we would prefer to live without having to define or classify or rank, but you know where you have limited resources you are always going to have some kind of ranking process, so if you don't have a ranking process based on equity profiles, you will have a ranking process based on financial need. 
Despite the normalising of classification and the prevailing view amongst practitioners that it is ordinary and unproblematic, the example above shows that the ordinary and normative is sometimes rendered extraordinary, and disrupts what is expressed by many practitioners and employers as an unproblematic process.

\section{Challenges of classification}

The challenges of classification on the basis of race at UKZN identified by interviewees mainly relate to 'misclassifications' (a term that holds true only if there is a notion of true/accurate classification of race). These cases of misclassification result from a myriad of problems including:

1. Problems with inaccurate data capturing. For example the data capturer could accidentally misclassify someone, or even make a subjective judgement call and change the person's selfclassification to match a racial category deemed more appropriate by the data capturer.

2. The difficulties in making judgements of race classification in a society that is increasingly integrated and becoming increasing racially mixed. This problem extends beyond the mixed race category of 'coloured' (Erasmus, 2007).

3. The problem presented by the current four categories in use (African, Indian, Coloured and White). The use of these four categories has meant that Chinese South Africans, for example, have seen their identity collapsed under the generic category of Black. Racial classification in this sense assumes an economic currency and imperative (see Erasmus and Park, 2008) when related to Broad-Based Black Economic Empowerment (BBBEE) for example.

4. The challenges related to race classification where it is perceived to relate to access to jobs, funding or placement at University were noted.

\subsection{Misclassification}

The problems relating to 'misclassification' have been referred to previously. This results from human error in capturing data provided, as mentioned above, and subjective and arbitrary 'corrections'. Respondents dealing directly with student and staff classifications indicated that in their opinions employees and staff often misrepresented their classification. When prompted as to how individuals can err in self-classification, respondents argued that it was often an attempt to secure access to financial resources or a deliberate attempt by academic staff to hinder transformation processes. Therefore, for example, it can be argued to 
be a 'moral' error in the eyes of the classifier: race classification has consequences, so the self-classifier has to accept not only the classification as common-sense, but also the consequences, whether favourable or not.

The act of self-classification by its very nature cannot be an inaccurate one. Classifiers however deem that it can be. They argue that they are objective observers who can recognise the phenotypic and other markers, such as surname, place of residence and schooling, that may challenge the race that individuals have classified themselves as - races are facts and confirmed by further facts. That surnames, areas of domicile, schools and other apartheid markers of race (such as the Group Areas act) are no longer active in South Africa does not deter these practitioners of classification from still using these criteria to challenge the selfclassifications by individuals. The assumption that apartheid era classification processes were somehow completely objective, scientific and not socially constructed, also informs their analysis. If the apartheid bureaucrats could be so confident about the veracity of its project of racial classification, so too can the post-apartheid bureaucrat.

Attempts to resolve apparent instances of misclassification, however, can be problematic: firstly, because of the discomfort inherent (for some) in the process of categorising people on the basis of race; and, secondly, because of changes in society that make 'traditional methods, ${ }^{14}$ of classifying people increasingly ambiguous, or even inappropriate. The following extract from an interview is an illustration of this:

It has happened from time to time that you would find a student who's either, their schools that they've been to, their area that they live in, the surname would not match what I would expect for an African student, and so you would then need [....to...] unpack and get the student into the office and of course you well know the difficulty [the] apartheid government had in classifying people, you know how do you classify people on the basis of what you see in the office, who makes the judgement call? And so those are the difficulties and we live with them on a day to day basis. [...]

Let's give a hypothetical situation, where you have a student who has classified themselves as African they have a European surname, they've been to Westville Girls High School, they live in Westville, you would need perhaps to ask some questions you know, who was your mother, who was your father and try and unpack it on that basis, whether this is a pure African situation or whether we're talking mixed marriage to two or three generations (Interview Morrison, 2009).

Furthermore, the four categories in use (discounting 'Other' and 'Foreigner') are limited in scope and sometimes result in misclassifications as a result. For example, it was pointed out in a few interviews that there has been some difficulty in classifying Chinese people as they do not fit easily into the four available categories. This is especially problematic when it

\footnotetext{
${ }^{14}$ Such as residential area or school, which under apartheid and the provisions of the Group Areas Act, were generally congruent with race.
} 
comes to classifying international students, who have also have to be classified upon arrival to study at the UKZN.

\subsection{The 'Coloured' question}

Classifying people of 'mixed race' heritage is becoming more and more difficult and this challenge was noted by a number of respondents. 'Coloured' in South Africa may be understood to refer to people of 'mixed race' heritage but it is also sometimes seen as tied to a particular cultural identity, that of 'Cape Coloured'; or of specific races in the mix. ${ }^{15}$ As a result, people of mixed race heritage that do not belong to this cultural formation that is tied to a 'black-white' racial heritage may feel uncomfortable adopting this category for classification. Interviewees observed:

The one might be when it comes to this classification of coloured which is a bit of a, you know, what does it mean (Interview Fihlela, 2009).

If they want to keep the mixed box or the bi-racial box they can maybe have subsections under that because I think that is really going to grow in the future. There's more interracial families [...] coming forward (Interview Van Soelen et al, 2009).

\subsection{Employment equity and quotas}

The challenge posed by classification linked to access to a job or higher education in a chosen field is particularly difficult as illustrated previously. This is especially the case given the stated acceptance of the need for redress both in employment and in access to higher education.

I just relate an experience from one of the interviews that we had where a person asked us if race was going to play any part in the short listing of candidates and the chairperson said yes it's a South African reality. But this person we were interviewing him from London although he is a South African but I think he probably wasn't really satisfied with that answer if race was going to sort of be a factor in the short listing of candidates. But I mean it's South Africa, people have to understand where we come from. I think we can go with this idea that I am a human being why should race be an issue but this is South Africa there's no way we can just ignore that. Definitely not, whether we like it or not for the next few years, I don't know how many (Interview Fihlela, 2009).

\footnotetext{
${ }^{15}$ Under the Population Registration Act (30 of 1950) as amended in 1959, the Coloured group was divided into subgroups consisting of Cape Coloured, Malay, Griqua, Chinese, Indian, Other Asiatic and Other Coloured (Erasmus, 2007). The last subgroup was defined basically in the negative as anyone who did not fit into one of the other subgroups and was neither white nor black (or 'native').
} 
The challenge of race-based affirmative action relates largely to the need to maintain an appropriate balance between excellence and redress. Whilst not necessarily contradictory in its application, it could also display the problematic assumption that the two are goals are in absolute conflict. Interviewees commented:

So somebody would argue that if we have an applicant who's a Nobel Laureate, and he's white and male do you exclude that person from the selection process just because of a racial category and then also sort of ignore the idea of excellence because you want to attract excellence at the same time? So, we get caught in this quandary, and this quandary belongs to the selection panel to decide on and whatever decision they make will only be addressed if there's somebody contesting it (Interview Govender, 2009).

There are of course problems in the sense that we have to turn away a very large number of high performing students [from the Medical School] which from an education perspective you wouldn't like to do, but if you wouldn't do that, if you wouldn't apply a quota system, we would end up being a medical school for only Indian and White students (Interview Sturm, 2009).

Clearly the issue of quotas and employment equity continues to remain a divisive issue in work organisations, especially universities. The first challenge, faced by universities like UKZN for example, is that racial transformation either through quota polices or other measures like affirmative action have to be nuanced and move beyond racial classification as the primary tool of achieving a more egalitarian institution. The second challenge is that these equity goals (racial, gender, class) can only be successfully achieved with sufficient financial and human resources. UKZN is currently struggling with both these resources. The creation of diversity and equity portfolios does not automatically suggest that an institution is taking these issues seriously. These may well be the driving forces of employment equity, but in order for their goals to be achieved sufficient financial and human resources need to be supplied and made available.

\section{Commentary and Conclusions}

...there's a strong view held by many people on affirmative action, employment equity and so on but I don't think that extends to really being too concerned with ticking boxes with race (Interview Wills, 2009).

While the motivation of achieving diversity - rather than racialised representivity - in the University as workplace, of both staff and students, is not often used it has some relevance. However, as it hardly featured in the interviews, it will not be discussed here. The interviews elicited views that related race classification to redress and the demands of the Employment Equity Act. 
Practitioners of racial classification in work organisations are often surprised by the infrequent agency of those they classify racially, such as displayed through questioning and contesting their classification. They are further surprised that the objection should be raised that such classifications are subjective and have no scientific basis. Many of these practitioners have not been trained before or after their employment in critical social sciences. At a senior level, where practitioners have some training or understanding of the complexities of social identity, there is a firm divide in their thinking between the philosophical-moral questioning of attributing essentialised racial belonging, and the pragmatic work of classifying employees racially.

Human resource practitioners often cite the sensitive and sometimes volatile nature of their work when engaging in racial classification. For example, they are confronted by a range of obstacles when attempting to implement racial redress policies. They further contend that stereotypes and prejudice in the workplace are at their worst when organisations are asked to either have their employees classify themselves or organisations classify employees.

Racial classification in a work organisation such as a South African university is used largely to measure transformation of two distinct groups: employees and students. The purpose of classification differs slightly in each case. For employees, race classification is understood to be necessary on a practical level in order to fulfil legislative requirements (in terms of the Employment Equity Act), and, some interviewees expressed the need for the University to be transformed away from its historically white origins. For example respondents Fihlela and Govender both reiterate the need for the use of racial classification as normative and necessary to address racial inequities. For these respondents, classification is a necessary bureaucratic exercise used to achieve and measure in a statistical way racial parity and equity amongst students and staff at UKZN.

For example, Fihlela points out that:

... without classification you will never be able to see whether you are doing well or not. For me that's what I think it’s all about, you know (Interview, 2009).

Similarly respondent Govender contends that any serious approach to achieving equity at UKZN is dependent on the use of racial classification. Govender argues that:

If you're serious about redress you have to use racial categories. [...] Identifying racial groups basically allows us to employ instruments to correct [...] and to raise the different capabilities of people [...] So we have to work with that. Society can't just level itself off automatically you know we have to make conscious interventions, unfortunately equity planning, let’s call it that, is sort of necessary (Interview, 2009). 
The rationale of both these arguments has two premises. Firstly, that race as an absolute category exists and all people are, therefore, classifiable. Secondly, that the act of classification allows for a benchmark to ensure racial redress and the achievement of legislatively mandated equity goals. Govender (Interview, 2009) acknowledges that for him the 'purpose of classification is simple' and that most employees are happy either to classify themselves or be classified by HR selection officers. He does recount one incident when the race of an applicant for a job was unclear to him. He had subjectively classified the applicant as white, but was not completely convinced that this was the correct classification. He then asked the selection panel what the applicant's racial classification was and was informed that the applicant was classified as coloured. It is not clear whether the applicant had classified herself as coloured in her $\mathrm{CV}$, for example, or that different members of the panel had in their own subjective cognitive schema classified the applicant.

The potential dissonance of this experience lies in the argument that racial classification is a simple process that is rational and empirical and serves a clear purpose for the classifier, in this case an HR practitioner. However, this argument is belied by the subjective moment of doubt that the manager had in making a decision about this particular applicant. Govender does not provide reasons for his 'misclassification' but argues instead that cases of misclassification are anomalous and that there have been no legal challenges by employees or potential employees (that he can recall) to challenge their assigned racial classifications.

In the case of students, race classification again is viewed as necessary, largely in order to measure progress in fulfilling the national transformation agenda and reporting on this process to Higher Education South Africa (HESA). This goal, according to some interviewees, has resource implications since government subsidies to the University may be adversely affected if UKZN was seen to be lax in fulfilling its mandate to transform access to higher education in South Africa. It is also necessary in order to fulfil University-driven quota-based acceptance of applications to study at the University. From all the Faculties at UKZN, the Medical School applies a quota-based system most stringently.

In a 2002 interview with the executive director of equity of the former University of Natal it was contended that for a long time the University met its student equity targets by classifying Indian students as Black. Being classified as 'generic Black' concealed that the university had not substantively increased its Black African student intake. The situation post-merger has changed significantly with most students of the merged institutions being classified as Black African. 
Investigating the purposes and practices of race classification in an institution of higher learning in South Africa offers a particularly interesting insight into these issues. The various people interviewed differed widely in their level of willingness to engage openly in a discussion on race and in some instances were quite suspicious of the researchers' intentions in undertaking this research. This is likely a reflection of the continuing sensitivity of the reincarnation of a previous apartheid era practice, as well as institution-specific tensions around race.

In addition, it is interesting to note that, as reflected in the quote at the head of this Conclusion, while most people, according to the interviewees, are quite comfortable or at least unconcerned with the idea of selecting a particular racial category with which they would be classified, there is a definite tension associated with some of the processes and consequences of these processes that are enabled by race classification, like affirmative action and differential access to financial resources. We repeat, however, that we did not explore the effects of classification on those being allocated to categories in this way.

Nevertheless, while most interviewees (classifiers themselves) were accepting of the need for race classification in order to achieve redress and for more pragmatic statistical and reporting purposes, there were some dissenters:

Except for the equity issues, I don't think it's necessary because what I think it does is it perpetuates these differences in all of us and I think in some ways we still carrying [...] the apartheid era which I find to be problematic because if we want to get rid of that then we've got to get rid of the old institutions as well, and part of that is classification, because I see that as an institution that actually promoted and perpetuated racial classification (Interview Gopal, 2009).

It is important to note that the redress discourse in South Africa has become conflated with racial redress, and interviewees automatically read redress to imply racial redress. When four of the senior human resource officials were asked if redress can occur beyond race, all agreed that it could, but suggested that such a mandate to link redress beyond race would have to come from the state. In this sense they were merely following orders. The imagination to achieve redress beyond race exists amongst practitioners interviewed. However this imagination seems to be increasingly under attack by institutional and state polices obsessed with race as the main means of redress.

\subsection{Alternatives to race classification?}

Although for the majority of interviewees, there were no viable alternatives to race classification in order to achieve the goal of redress, some suggestions for alternatives were 
put forward, as is reflected below. In South Africa, inequality was and remains inextricably tied to socio-economic inequality. A class based system of redressing inequalities would also then arguably serve to redress racial imbalances as (see Maré, 2001; Habib and Bentley (eds), 2008; Alexander, 2007):

we should change it from race into social level or economic level or whatever you would call it because what we are seeing now is of the last two, three years is that you get a increased number of Black African students that come from the same socioeconomic background as the Indian and White populations so they should in fact compete at equal levels instead of at race level in my view. And then we should have specific places for the economically deprived who have gone through a different schooling system and have less chance, even if they are as intelligent as the rest, to get in (Interview Sturm, 2009).

The other kind of categories that you could work with would consist of, say age group you know you could target the youth. That's a useful category because we know in terms of the numbers that seventy percent of our youth who finish school haven't found employment... (Interview Govender, 2009).

At present and for the foreseeable future, however, race based classification will continue to be practiced as a means towards assessing success in Government's primary measures of redress,

[B]ut I think for now I don't see us saying that everyone is just a South African. I don’t see that happening in the next few years (Interview Fihlela, 2009).

'Race' remains a core organising principle of South African society, subtly (and sometimes overtly) directing the ways in which social relations and cultural formations are structured. As Maré states, 'through the banality of bureaucratic practice, and the confirmation of political discourse, race is every day created, confirmed, maintained, telling us what exists, what is desirable and what is possible' (2001: 88). It is necessary, therefore, to draw attention to and question these processes and practices that appear to be natural in their obviousness and that serve to reinforce 'common sense' understandings of society that are in reality anything but.

\subsection{Future Research}

This introductory study into institutional sites of racial classification has a raised a number of potential research questions on the issue of racial classification in work organisations:

1. Case studies of racial classification by human resource practitioners can be extended to private sector organisations to discover if private sector work organisations and practitioners interpret the national mandate for equity in the workplace in the same way as state funded institutions such as UKZN. 
2. Are human resource practitioners expected always to divorce the pragmatic from the critical reflexive (what was referred to as 'the philosophical') or do both these elements need to be reflected in their practice and training?

3. Does the act of classifying by the classifier constitute a form of power and power abuse (either intentionally or unintentionally). Is this, the act of classifying and suspending the social/philosophical, then a form of emotional labour performed in work organisations?

4. Locate organisational examples of best practice where redress has occurred successfully, without race categories or by encompassing race as one of many criteria for achieving workplace diversity; also raising a question about the way in which diversity is perceived and its relationship to equity.

5. Consequences for and effects on those classified and for society in the long-term?

6. Who benefits from race classification?

This research project, into practices of race classification, has shown, on a small scale, the contradictions and problems inherent in processes and practices of classification by focusing on the classifiers.

Current practices of race based classification appear to be based on ad hoc and subjective interpretations by individuals tasked with the responsibility to classify. Given the apparent banality of classification which results in the general acceptance of race categories, these practices are largely unquestioned until attention is drawn to them. 


\section{References}

Alexander, N (2007) 'Affirmative action and the perpetuation of racial identities in postapartheid South Africa', in Transformation 63.

Burr, A (1995) 'What is social constructionism?', in An Introduction to Social Constructionism. London: Routledge.

Christopher, A.J (2009) 'Delineating the nation: South African censuses 1865-2007', in Political Geography 28.

Eloff, T (1990) Government, Justice and Race Classification. Stellenbosch: Centre for Contextual Hermeneutics, University of Stellenbosch.

Erasmus, Y (2007) Racial (re)Classification during Apartheid South Africa: Regulations, experiences and the meanings of 'race'. Unpublished PhD thesis, University of London.

Erasmus, Y and Y.J Park (2008) 'Race classification, redress and citizenship: the case of the Chinese South Africans', in Transformation 68.

Erasmus, Y and L Stone (2009). Race thinking and the law in post-1994 South Africa. Final project report. The Centre for Critical Research on Race and Identity. Accessed on 8 October 2010 from:

http://ccrri.ukzn.ac.za/docs/FINAL\%20REPORT\%20ON\%20RACE\%20THINKING\%2010 \%20NOVEMBER\%202008.pdf.

Habib, A and K Bentley (eds) (2008) Racial Redress and Citizenship in South Africa. Cape Town: HSRC Press.

Holstein, JA and JF Gubrium (2004) 'The active interview', in D Silverman (ed) Qualitative Research: Theory, Method and Practice. Los Angeles: Sage.

Horrell, M (1958) Race Classification in South Africa - Its Effects on Human Beings. SA Institute of Race Relations.

Makgoba, M.W and J.C Mubangizi (eds) (2010) The Creation of the University of KwaZuluNatal: reflections on a merger and transformation experience. New Delhi: Excel Books. 
Maré, G (2001) 'Race counts in contemporary South Africa: “an illusion of ordinariness”', in Transformation 47 (2001).

Nobles, M (2000) Shades of Citizenship: Race and the Census in Modern Politics. Stanford CA: Stanford University Press.

Posel, D (2001a) 'What's in a name? Racial categorisations under apartheid and their afterlife', in Transformation 47.

Posel, D (2001b) 'Race and common sense: racial classification in twentieth century South Africa’, in African Studies Review, 44(2).

Ramji, H (2009) Researching Race: theory, methods and analysis. Maidenhead: Open University Press.

South Africa (2008) Report of the Ministerial Committee on Transformation and Social Cohesion and the Elimination of Discrimination in Public Higher Education Institutions. (2008) Education, Republic of South Africa.

South Africa (2003) Broad-Based Black Economic Empowerment Act (53 of 2003). Pretoria: Republic of South Africa.

South Africa (1998a) Employment Equity Act (55 of 1998). Pretoria: Republic of South Africa.

South Africa (1998b) Skills Development Act (97 of 1998) Pretoria: Republic of South Africa.

South Africa (1996) The Constitution of the Republic of South Africa (Act 108 of 1996). Pretoria: Republic of South Africa.

South Africa (1950) Population Registration Act (30 of 1950). Pretoria: Republic of South Africa.

University of Kwazulu-Natal v Makgoba and Others (17124/2005) [2009] ZAKZDHC 28 (17 July 2009). Accessed on the 12th October, 2010: http://test.saflii.org/za/cases/ZAKZDHC/2009/28.html. 
Van der Haar, M and D Yanow (2009) 'Problematizing policy categories for mobile groups: A historical analysis of population registration and statistical practices in the Dutch nationstate'. Paper presented at the Vrije Universiteit, Amsterdam.

Yanow, D and M van der Haar (2009) 'People out of place: Allochthony and autochthony in Netherlands identity discourse - metaphors and categories in action'. Paper presented at the International Studies Association Annual Conference, New York. 
Appendix 1: Some forms requiring race classification (attached) 


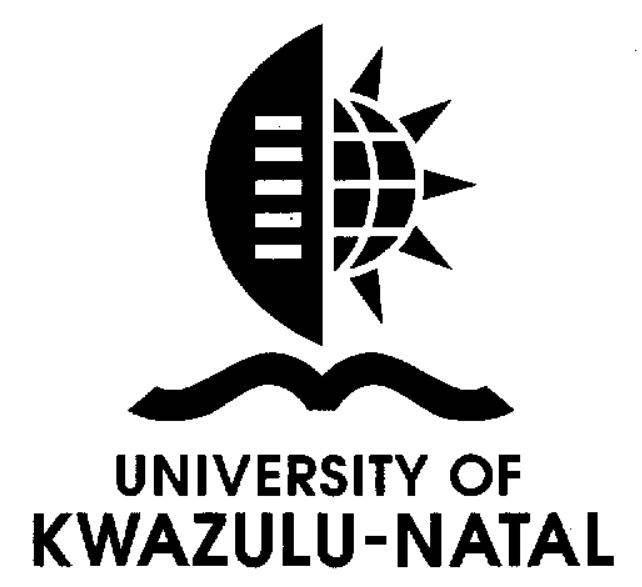

\section{APPLICATION FOR \\ UNDERGRADUATE ADMISSION \\ (International and Local)}

Note: Completed applications for all campuses must be forwarded to the Applications and Information Office at:

University of KwaZulu-Natal

Applications and Information Office

Durban

4041

FOR OFFICE USE ONLY:

NAME:

STUDENT NO: \begin{tabular}{|l|l|l|l|l|l|l|l|l|}
\hline & & & & & & & & \\
\hline
\end{tabular}

DEGREE/DIPLOMA:

LOCAL:

INTERNATIONAL: 


\section{Please read these notes before completing the attached application form}

1. The non-refundable application fee MUST accompany this application form. Application fees sent by post should be paid by cheque or postal order, not cash. Intemational and local applicants: Application fees can be paid by electronic transfer/bank deposit. The banking details are as follows:

Name: University of KwaZulu-Natal Acc. No: 50871932932

Branch Code: 223626

Reference: F001 32020 with applicant's full name

Bank: First National Bank

Branch: Durban Corporate

Swift code: FIRNZAJJ - Durban Corporate branch

2. The application form MUST be completed as fully and as accurately as possible to avoid delay in processing. Use names appearing on the identity document or passport when completing this form. The completed application form must be accompanied by proof of application fee payment.

3. The University of KwaZulu-Natal is an English medium university. International students from non-English speaking countries must provide proof of English proficiency. Please refer to the Essential Information Booklet for further information.

4. Applicants whose previous degrees were obtained at a university other than University of KwaZulu-Natal must submit certified copies of their previous degree certificates with their application. For international applicantsi Please provide translated copies where applicable. Also refer to the Essential Information Booklet for further information.

5. If you have attended another university you must arrange for the Registrar of that University to submit to this University a full academic record for all years of study and a certificate of conduct.

\section{Closing dates and Application Fees}

\begin{tabular}{|c|c|c|c|}
\hline A. U & ndergraduate Applications & Closing & Applic. Fee \\
\hline $\begin{array}{l}1 . \\
1.1 \\
1.2 \\
1.3 \\
1.4\end{array}$ & $\begin{array}{l}\text { South African Applications } \\
\text { Medicine (no late applications } \\
\text { accepted) } \\
\text { Architecture/Engineering/ Health } \\
\text { Sciences/Science } \\
\text { Education/Humanities/Law/ } \\
\text { Management/SFP } \\
\text { Late applications for } 1.2 \text { and } 1.3 \\
\text { if spaces are available }\end{array}$ & $\begin{array}{l}30 \text { June } \\
30 \text { Sept } \\
31 \text { Oct }\end{array}$ & $\begin{array}{l}\text { R205 } \\
\text { R205 } \\
\text { R205 } \\
\text { R315 }\end{array}$ \\
\hline $\begin{array}{l}2 . \\
2.1\end{array}$ & $\begin{array}{l}\text { International Applications } \\
\text { For semester } 1 \text { (Feb-June) } \\
\text { For semester } 2 \text { (Aug-Dec) }\end{array}$ & $\begin{array}{l}30 \text { Sept of } \\
\text { previous year } \\
30 \mathrm{Apr} \text { of } \\
\text { current year }\end{array}$ & $\begin{array}{c}\text { SADC \& } \\
\text { countries } \\
\text { in Africa: } \\
\text { R320 } \\
\text { Countries } \\
\text { outside } \\
\text { Africa: } \\
\$ 90\end{array}$ \\
\hline
\end{tabular}

\section{Entrance Requirements:}

\section{Legal entrance requirements:}

The NSC for degree admission or Senior Certificate with matriculation exemption (or equivalent) is required for admission to degree studies in South Africa. Candidates who have passed in an alternative access programme approved by the Senate of this University. will qualify for a Conditional Senate Exemption and may be considered for admission to degree studies.

Applicants with non-South African school leaving qualifications need to ensure that they qualify for admission to degree studies at South African universities in terms of the guidelines provided by the Higher Education South African Matriculation Board (HESA). Please refer to their website at: unw.hesa.org.za. Further information can be obtained from:

1. The Matriculation Board at Tel: $+27(0) 124812848 / 7$ or

2. University of KwaZulu-Natal Applications Office at Tel: +27 (0)31 $2602212 / 7877$ or

3. University of KwaZulu-Natal International Office at Tel: +27 (0)312601092.

\section{Faculty entrance requirements:}

In addition to the legal entrance requirements, South African applicants should also meet the minimum points for specific programmes. All applicants should also meet subject requirements and levels of performance for admission to certain programmes. Also note that the number of applications received by far outnumber the spaces available at University. Meeting the minimum requirements for application does therefore not guarantee admission to the University. Therefore meeting the minimum requirements for application does not guarantee admission to the University.

\section{Students with disabilities}

Please contact the Co-ordinator at the Student Counselling Centre for information on services, equipment and support available to students.

Howard College - Tel: +27 cos312603070/1310

Pietermaritzburg - Tel: +27 (0)33 $2605959 / 5233$

Westville - $\quad$ Tel: +27 (0)31 $2607706 / 7888$

Edgewood - Tel: +27 (0)312603665

\section{Needing Assistance:}

If you need assistance in selecting programmes, choosing your majors, career or personal guidance. or testing you can contact a counsellor at one of our Student Counselling Centres:

Edgewood - $\quad$ Tel: $+27(0) 312603665$

Howard College - Tel: +27 (0)31 $2602668 / 2669$

Medical School - Tel: $+27(0) 312604595$

Pietermaritzburg - Tel: $+27(0) 332605233$

Westville -

Tel: $+27(0) 312607337 / 7087$

\section{Financial Aid Queries:}

NOT APPLICABLE TO INTERNATIONAL STUDENTS

For all financial aid queries please phone the relevant campus:

Edgewood -

Howard College - Tel: +27 (0)31260 2231

Medical School - Tel: +27 (0)31260 4352

Pietermaritzburg - Tel: +27 (0)33 2605915

Westville - $\quad$ Tel: +27 (0)31260 7912

\section{Residence Queries}

For all residence queries please phone the relevant campus:

Edgewood -

Howard College -

Medical School -

Pietermaritzburg -

Westville -
Tel: $+27(0) 312603611$

Tel: $+27(0) 312602028$

Tel: $+27(0) 312602028$

Tel: $+27(0) 332605915$

Tel: $+27(0) 312607912$ 


\section{APPLICATION FOR ADMISSION \\ FOR OFFICE USE ONLY: \\ Student no: \\ App Fee Pd: R \\ Date: \\ Receipt No: \\ Into ITS By: On:}

uxyessmot

KWAZULU-NATAL

\section{TERM OF ENTRY AND CHOICE OF PROGRAMME}

- Have you been registered as a student at University of KwaZulu-Natal before? YES $\square$ NO

- If yes, what was your Student No.?

Year of entry: \begin{tabular}{|l|l|l|l|}
\hline 2 & 0 & & \\
\hline
\end{tabular} Entry Term: Semester:

Degrees/Diplomas/Programmes applying for:

FFICIAL USE

\begin{tabular}{|c|l|l|l|l||l|}
\hline $\begin{array}{l}\text { Choice } \\
\text { Order }\end{array}$ & Campus & Name of Degree/Diploma & Major/Programme & $\begin{array}{l}\text { Full or } \\
\text { part-time }\end{array}$ & Approved \\
\hline 1 & & & & & Date \\
\hline 2 & & & & & \\
\hline 3 & & & & & \\
\hline 4 & & & & & \\
\hline
\end{tabular}

\section{PERSONAL DETAILS}

Title: $\mathrm{Mr} \square \quad$ Mrs $\square \quad$ Miss $\square$ Ms $\square$. Other

Sumame:

First Names:

Maiden Name:

ID No:
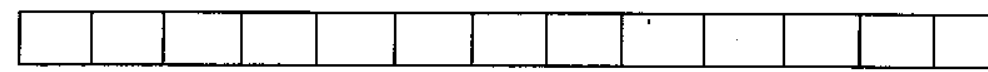

(South African Applicants only)

Persal number:

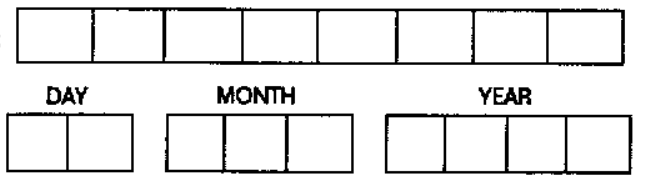

Date of Birth:

Married

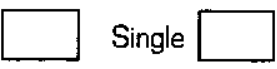

(teacher only)

Marital Status:

Race: African Coloured $\square$ Indian

Divorced

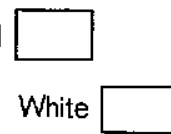

Widowed Separated

Other: (specify)

Gender: Male $\square$ Female $\square$

Home Language: Nationality:

Religion (optional):

\section{RESIDENCY}

- Are you a permanent resident of SA?

YES

NO

- If not, what is your country of permanent residence?

- Passport No.:

- Expiry Date

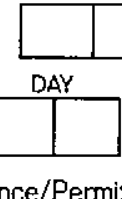

- Study/Residence/Permit No:

- Expiry Date:
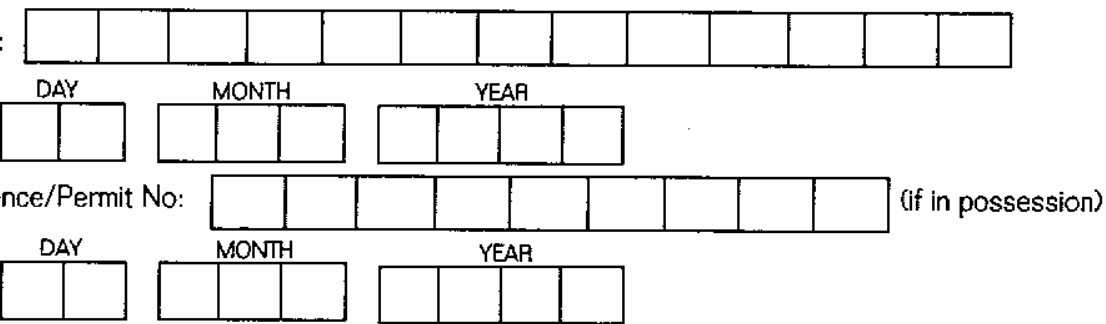

$$
\text { MONTH }
$$

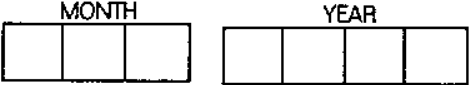




\section{FINANCIAL ASSISTANCE}

\section{NOT APPLICABLE TO INTERNATIONAL STUDENTS}

Do you wish to apply for financial assistance?

YES

NO

\section{POST-SCHOOL ACTIVITIES}

Present activity (Please tick)

\begin{tabular}{|l|l|l|}
\hline *University student & 01 & \\
\hline Teacher's Training College & 02 & \\
\hline Technikon Student & 03 & \\
\hline College of Nursing student & 04 & \\
\hline
\end{tabular}

\begin{tabular}{|l|c|l|}
\hline Technical College student & 05 & \\
\hline Labour Force (Employed) & 07 & \\
\hline Standard 10 pupil/Grade 12 learner & 08 & \\
\hline OTHER ( & 10 & \\
\hline
\end{tabular}

* If university student, please state name of last institution in section 8 on page 5 and submit academic record and certificate of good conduct: NOTE: The code structure has been set up (by ITS) in terms of government reporting requirements.

\section{If you are employed please complete the following: \\ Name of Company/Institution}

Address of Company/Institution

\begin{tabular}{|l|l|l|l|l|l|l|l|}
\hline Postal Code & Telephone No. (Work): & \multicolumn{4}{|l|}{} & \multicolumn{2}{|l|}{ Area dialling code: } \\
\hline Fee Account to Employer & Yes & & No & & & \\
\hline
\end{tabular}

- Have you applied for admission through an access programme?

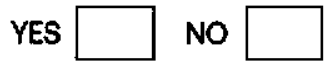

- If "Yes", indicate which programme \begin{tabular}{|l|l|l|l|l|}
\hline BMC & SCIENCE \\
\hline
\end{tabular}

\section{ADDRESS AND CONTACT DETAILS}

Postal Address:

Town/City:

Country: Postal Code:

Physical address:

Town/City:

Country: Postal Code:

Telephone Numbers:

Cell phone:

Work: Dial code:

Home: Dial code:

Email address: No: No:

Work/Home Fax:
Guardian/Parent (if under 21) or next of kin:

Name:

Address:

CBO

Telephone Numbers:

Work: Dial code:

Home: Dial code:

No:

Cell phone:

Email:

Relationship:

$\begin{array}{lll}\text { Father } \square \text { Mother } \square & \text { Spouse } \square \\ \text { Brother } \square & \text { Sister } \square \\ \text { Child } \square \text { Garent } \square & \text { Other } \square\end{array}$




\section{HIGH SCHOOL DETAILS}

Year of last school leaving certificate (equivalent to Grade 12):

Name of school certificate/diploma:

Examination No:

\section{NB: INTERNATIONAL STUDENTS TO CHECK EQUIVALENCE WITH MATRICULATION BOARD}

Type of Matriculation Exemption already held: (Please tick one)

\begin{tabular}{|c|l|l|l|l|l|}
\hline 01 & Full Exemption & & 07 & Other Senior Certificate \\
\hline 03 & Ordinary Conditional & & 08 & NTC3/N3/NSC \\
\hline 04 & Mature Age Exemption & & 09 & Standard 10 Practical & \\
\hline 05 & Foreign Exemption & & 10 & Other & \\
\hline 06 & Immigrants Exemption & & 11 & Discretionary Provision (Senate exemption) & \\
\hline
\end{tabular}

NOTE: The code structure has been set up (by $\mathrm{TS}$ ) in terms of government reporting requirements.

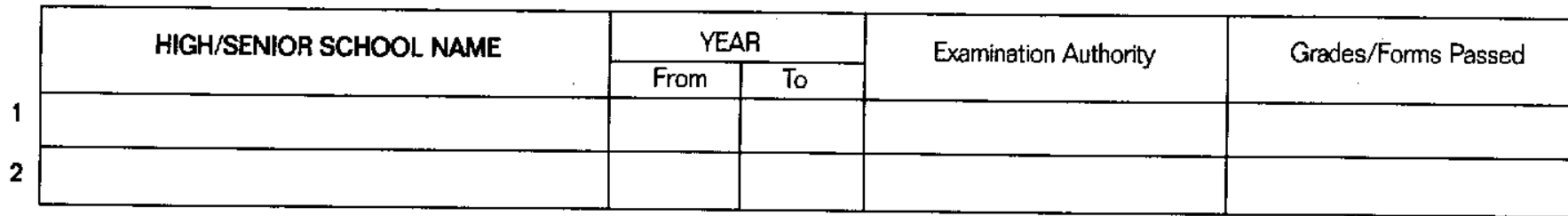

High School subjects (Intemational Students: state subjects of last school leaving certificate)

1
2
3
4
5
6
7
8

\section{PREVIOUS STUDIES}
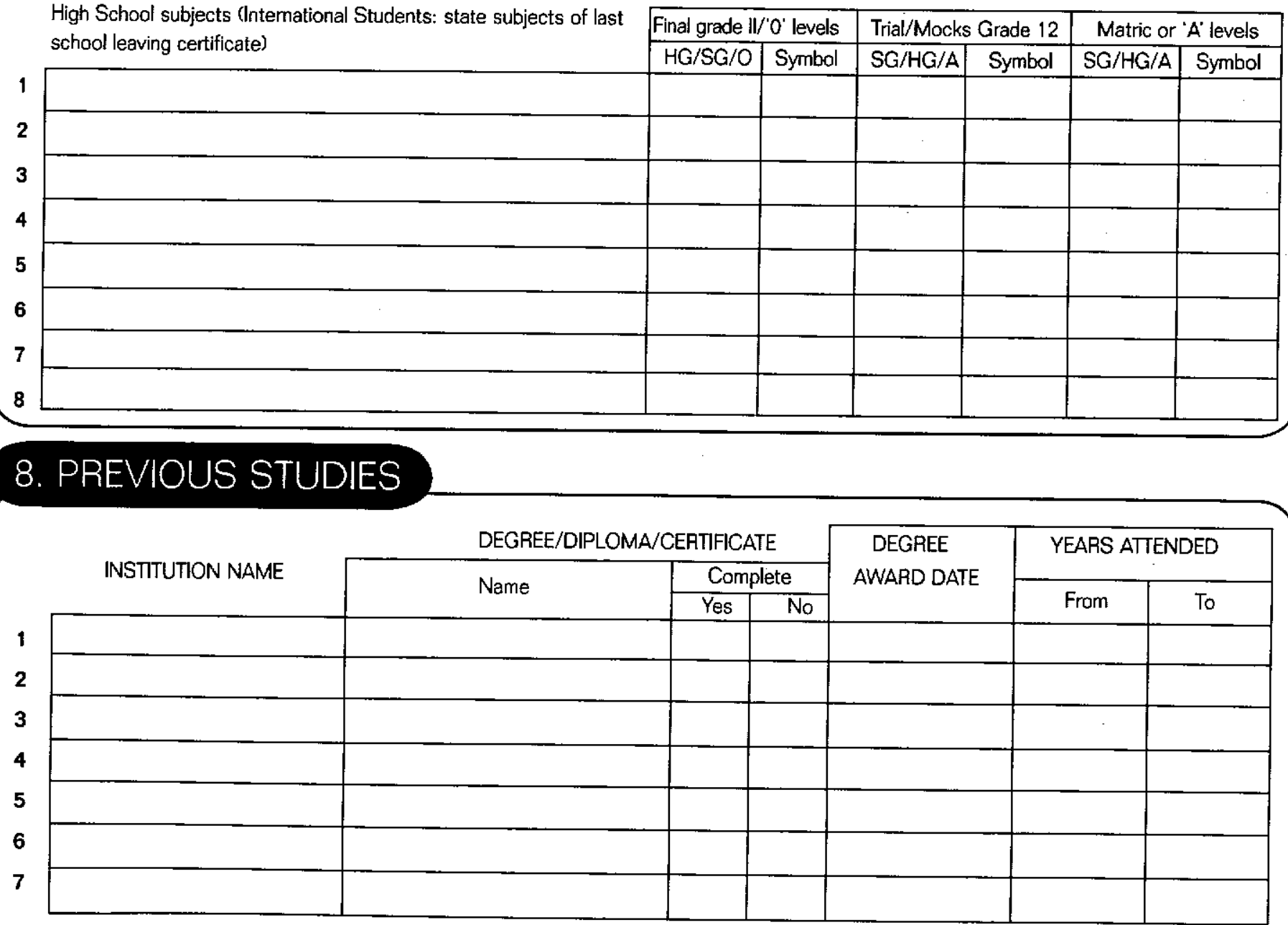

- Student number(s) at previous institution:

- Have you ever been refused entry to, expelled or excluded from another institution? If "Yes", provide the details:

No

- Have you ever been refused entry to, expelled or excluded from a residence of any institution? YES If "Yes", provide the details:

- Do you owe fees to another institution? If "Yes", provide the details:

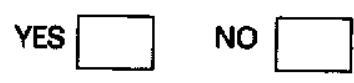




\section{MEDICAL INFORMATION}

\subsection{DISABILITY INFORMATION}

The University is sensitive to the needs of students with disabilities, and will attempt to provide support where possible.

Do you have any disability, physical or othenwise, that might require support?

YES

$\mathrm{NO}$

If "Yes", please indicate:

Persons with a Visual Impairment

Persons with a Physical Impaiment

$\square$ Blind

$\square$ Partially sighted

\section{$\square$ Uses a wheelchair}

Uses crutches/callipers

Persons with a Hearing Impairment

$\square$ Partially deaf

Mild to moderately deaf

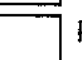

Persons with paraplegia/quadriplegia/ hemiplegia/post-polio paralysis

Other (please specify)

\subsection{COMPULSORY FOR INTERNATIONAL STUDENTS ONLY}

Health Insurance

I (name) confirm that I will/have applied for adequate health insurance cover while in South Africa.

Name of Health Insurance Company:

Address:

\section{RESIDENCE APPLICATION}

Do you wish to apply for admission to a University Residence?

YES

NO

If yes, which campus?

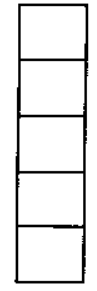

Howard College

Pietermaritzburg

Edgewood

Medical School

Westville

If you are unsuccessful in obtaining accommodation in a University Residence, where will you stay?

\section{GENERAL INFORMATION}

Do you wish your name/address to be kept confidential between yourself and the University?

YES

Persons with Diabetes

$\square$ Persons with Epilepsy

$\square$ Persons with Cerebral Palsy

Persons with Intellectual/Psychiatric/ Psychological Impairment

Persons with Medical/Chronic Ailments that require support (Please specify

Other (Please specify)

Note: Disclosure of information is subject to the Promotion of Access to Information Act and other relevant laws.

Did any of your immediate family study at this University?

If yes, state relationship to you:

YES

No

\section{ENGLISH PROFICIENCY}

\section{APPLICABLE TO INTERNATIONAL STUDENTS ONLY}

Students applying for admission into a degree programme at the University need to demonstrate that they have obtained one of the following levels of English proficiency:

1. A pass in an examination equivalent to English at South African National Senior Certificate (NSC) HL or FAL level or at the Higher Grade (First or Second Language) for the South African Senior Certificate.

2. A pass in English language at A-level, or O-level (C-symbol or higher), or the International Baccalaureate or equivalent examination.

3. For international applicants who do not satisfy (1) or (2) above and for whom English is a foreign language:

- an overall band score of 6.0 for Undergraduate studies, (7.0 for postgraduate studies) or

- a test score of 550 on the Test of English as a Foreign Language (TOEFL.

Test scores need to be submitted with application forms.

Name of document:

REFER TO ESSENTIAL INFO BOOKLET FOR MORE DETAILS. 


\section{DECLARATION AND UNDERSTANDING}

To be completed with the assistance of Parent/Guardian where applicant is not financially independent and under the age of 18 (a minor).

If my application is successful and I accept the offer of a place to study at the University of KwaZulu-Natal,

1. I undertake

1.1 To comply with the procedures, rules and regulations of the University of KwaZulu-Natal.

1.2 To inform the Registrar immediately, in writing, if I change my address.

1.3 To acquaint myseff with all the rules and general regulations that relate to the degree for which $I$ am applying.

1.4 To make altemate arrangement for accommodation should the University accept me for the degree and cannot offer me accommodation.

2. I We hereby accept liability for the payment of all tuition fees or other fees which may be charged by the University as a result of my/his/her studies at the University.

3. I am aware that my enrolment is valid only if it complies with the regulations of the degree concerned, notwithstanding the acceptance of this application by the University.

4. I/We accept the responsibility of submitting all documents required by the University before the stipulated due dates.

5. I declare

5.1 That I make this application and give the declarations and understandings with the knowledge and consent of my parent/guardian/employer.

5.2 I warrant that the information contained herein is true and correct and the University shall be entitled to declare the contract void and cancel my registration if I have made any misrepresentation or omission on this application.

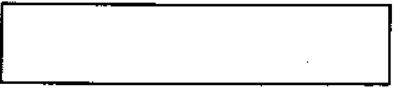

Signature of Student

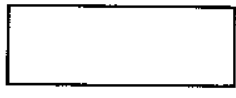

Date

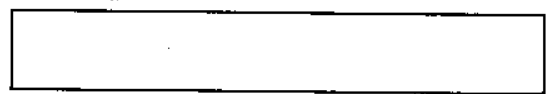

Signature of Parent/Guardian

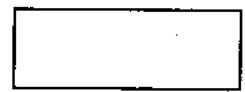

Date

\section{SURETYSHIP To be completed where applicant is not finanncially independent and under the age of 18 (a minor).}

I. the undersigned lawful parent/guardian of the applicant, do hereby bind myself to the University of KwaZulu-Natal as surety in solidium and co-principal debtor with the above-named applicant for the due payment of all fees and other charges due and payable to the University of KwaZulu-Natal in terms of the relevant applicable annual schedule of fees. The surety will operate as a continuing covering suretyship. I agree that I will not be released from liability under this suretyship in any circumstances what ever, except with the University of KwaZulu-Natal's written consent and in particular, I shall not be released by reason of the fact that the aggregate amount owed to you by the applicant may fluctuate and may at times be nil.

Please print full name of Surety/Parent/Guardian:

Identity no:

Address:

Which will be my domicilium citandi et executandi (permanent residential address) for all purposes under this document which means that I will accept service of all notices, documents and legal proceedings against me. In the event of my changing this address I agree to inform the Student Debtors Section of the Finance Department of the University of KwaZulu-Natal of any change in my address.

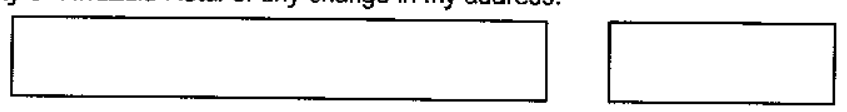

Signature of Parent/Guardian

Date

\section{CHECKLIST}

Please ensure that the following relevant documents are enclosed with this application:

- Have you indicated your choice of degree/diploma and campus?

- Have you enclosed the proof of payment or non-refundable application fee?

YES

YES
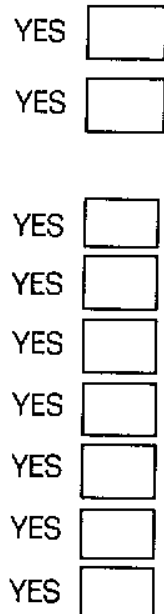

Compulsory for

international

students only

English translation

- Copy of Degree Certificate (if studied previously) $\int$ if applicable

- Copy of National Senior Certificate/Senior Certificate/Matric Certificate/O/A Levels or relevant school leaving qualification/certificate

- Study Permits

- Proof of English Proficiency

- Proof of Medical Insurance

YES

YES

YES

Have you completed the financial assistance section (4) if applicable?

Have you filled in the application form in full?
YES

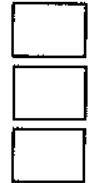

NO

NO

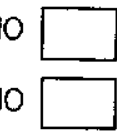

No

NO

NO

NO

NO

NO

NO

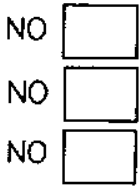




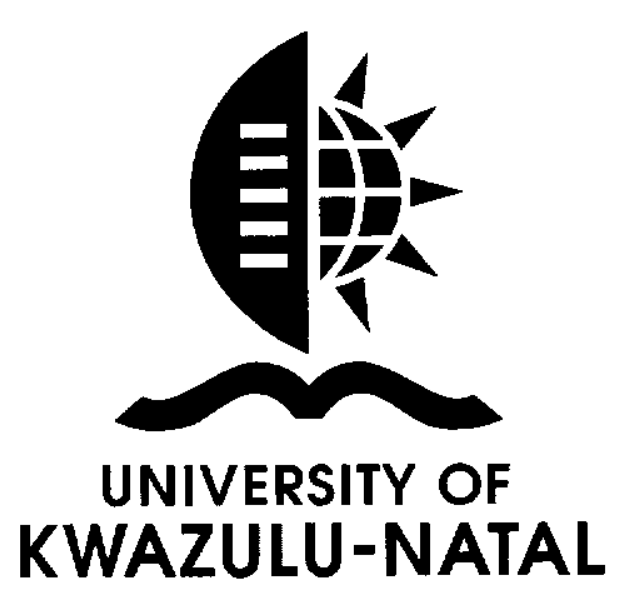

\section{APPLICATION FOR POSTGRADUATE ADMISSION (International and Local)}

Note: Completed applications for all campuses must be forwarded to the Applications and Information Office at:

University of KwaZulu-Natal

Applications and Information Office Durban 4041

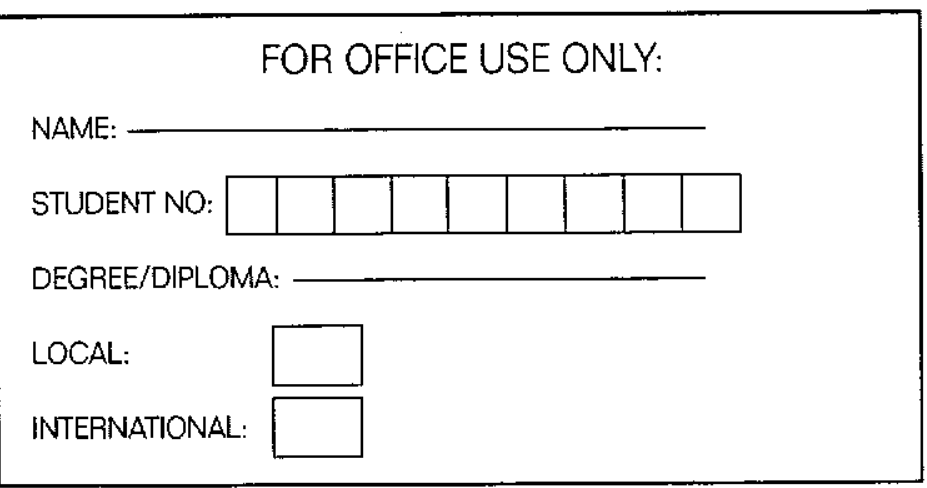




\section{Please read these notes before completing the attached application form}

1. The non-refundable application fee MUST accompany this application form. Application fees sent by pest application form

International and local applicants: Application fees can be paid by electronic transfer/on fees sent by post should be paid by cheque or postal order, not cash.

2. The application form MUST be completed as fully and as accuratectronic transfer/bank deposit. when completing the form. proficiency. Please refer to the Essential Information Booklet for further infomal students from non-English speaking countries must provide proof of English

4. Applicants whose previous certificates with their application. International applicants: Persity other than University of KwaZulu-Natal must submit certified copies of their previous degree Information Booklet for further information.

5. If you have attended another university study and a certificate of conduct.

\section{Application Fees:}

Local Students

SADC \& countries in Africa

Countries outside Africa

The banking details are as follows:

Name: University of KwaZulu-Natal

Bank: First National Bank

Acc. No: 50871932932

Branch: Durban Corporate

Branch Code: 223626

Swift Code: FIRNZAJJ - Durban Corporate branch

Reference: F001 32020 with applicant's full name

Please provide your details on the deposit slip and submit proof of payment on submission of your application.

\section{Closing Dates:}

Please refer to the Postgraduate Application Guide for information on the closing dates for each College/Faculty.

\section{Students with Disabilities:}

Please contact the Co-ordinator at the Student Counselling Centre for information on services, equipment and support available to students.

Howard College - Tel: +27 (0)31 $2603070 / 1310$

Pietermaritzburg - Tel: +27 (0)33 260 5959/5233

Westville -

Edgewood -

Tel: $+27(0) 312607706 / 7888$

Tel: $+27(0) 312603665$

\section{Needing Assistance:}

If you need assistance in selecting programmes, career or personal guidance, or testing, you can contact a counsellor at one of our Student Counselling Centres:

Edgewood -

Howard College -

Medical School -

Tel: $+27(0) 312603665$

Pietermaritzburg -

Westville -

Tel: $+27(0) 312602668 / 9$

Tel: +27 (0)31 2604595

Tel: +27 (0)33 2605233

Tel: $+27(0) 312607337 / 7087$

\section{Evaluation:}

International applicants are advised to have their qualifications assessed by the South African Qualification Authority (SAQA) They can be contacted at:

Tel: +27 (0)12431 5070 or

Email: ceeq@saqa.org.za or

Consult: urww.saqa.org.za

\section{Residence Queries:}

For all residence queries please phone the relevant campus:

Edgewood -

Howard College -

Medical School -

Pietermaritzburg -

Westville -
Tel: $+27(0) 312603611$

Tel: $+27(0) 312602028$

Tel: $+27(0) 312602028$

Tel: +27 (0)33 2605915

Tel: +27 (0)312607912 


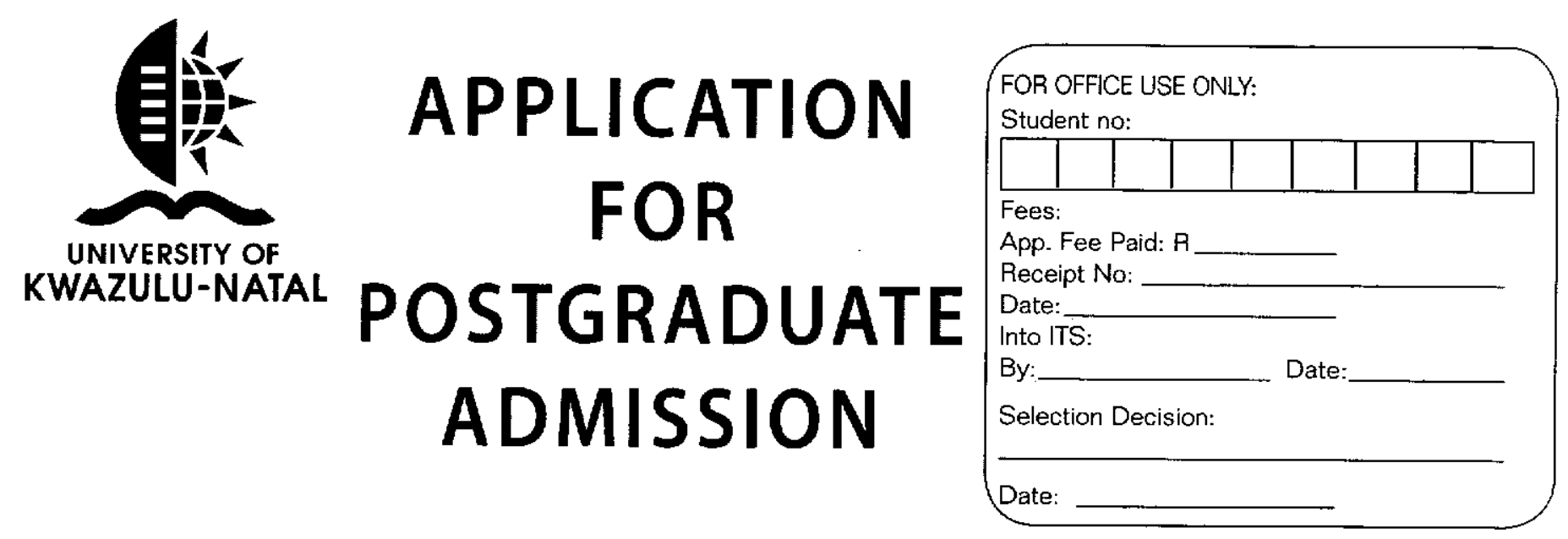

\section{DEGREE FOR WHICH APPLICATION IS BEING MADE}

- Have you been registered as a student at University of KwaZulu=Natall/University of Durban-Westville before? YES

- If yes, what was your Student No.?

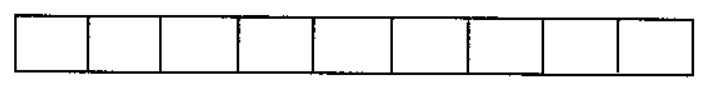

Year of entry:- \begin{tabular}{|l|l|l|l}
\hline 2 & $0^{-}$ & & \\
\end{tabular} Entry Term: Semester: $1 \square \square 2 \square$ Year of study for this degree/diploma (eg. 1st): $\square$.

Degrees/Diplomas/Programmes applyitig for:

OFFICIAL USE

\begin{tabular}{|c|c|c|c|c|c|c|}
\hline $\begin{array}{l}\text { Choice } \\
\text { Order }\end{array}$ & Campus & Proposed Degree/Diploma & Programme/Discipline & $\begin{array}{l}\text { Full or } \\
\text { part-time }\end{array}$ & Approved & Date \\
\hline 1 & & & & & & \\
\hline 2 & & & & & & \\
\hline 3 & & & & & & \\
\hline 4 & & & & & & \\
\hline
\end{tabular}

*For Masters students only

Masters candidates: Is this a Coursework Masters?

YES

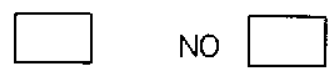

Medical Practitioners: HPCSA Registration number MP

\section{PERSONAL DETAILS}

$\mathrm{Dr} / \mathrm{Rev} / \mathrm{Mr} / \mathrm{Mrs} / \mathrm{Miss} / \mathrm{Ms}$ : Surname:

First Name: Middle Name(s):

Maiden Name (if applicable):

Gender: Male $\square$ Female $\square$

Marital Status: Married $\square$ Single $\square \quad$ Divorced $\square \quad$ Widowed $\square \quad$ Separated $\square$

Confidentiality:

Do you wish your name/address to be kept confidential between yourself and the University? Yes

Note: Disclosure of information is subject to the Promotion of Access to Information Act and other relevant laws.

Religion:

(optional)

Race: African $\square$ Coloured $\square$ Indian $\square$ White $\square$ Other (specify)

Home Language:

Date of Birth:

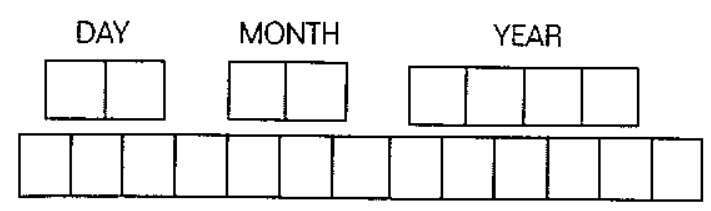




\section{RESIDENCY}

- Are you a permanent resident of SA?

- If not, what is your country of permanent residence?

- Passport No.:

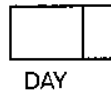

- Expiry Date DAY
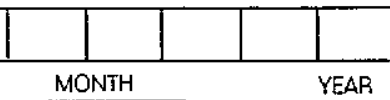

- Res Permit No.:

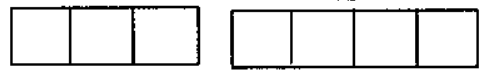

- Expiry Date:
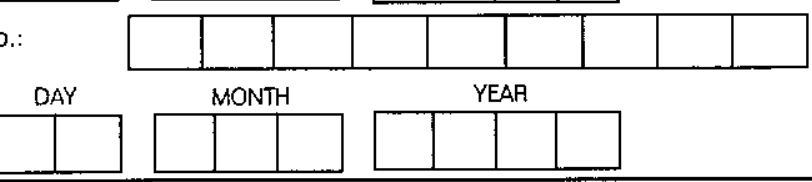

(if in possession)

\section{POST-SCHOOL ACTIVITIES}

Present activity (Please tick)

\begin{tabular}{|l|l|l|}
\hline *University student & 01 & \\
\hline Teacher's Training College & 02 & \\
\hline Technikon Student & 03 & \\
\hline College of Nursing student & 04 & \\
\hline
\end{tabular}

\begin{tabular}{|l|c|c|}
\hline Technical College student & 05 & \\
\hline Labour Force (Employed) & 07 & \\
\hline Standard 10 pupil/Grade 12 learner & 08 & \\
\hline OTHER ( & 10 & \\
\hline
\end{tabular}

* If university student, please state last institution and submit academic record and certificate of good conduct:

NOTE: The code structure has been set up (by ITS) in terms of government reporting requirements.

\begin{tabular}{|l|l|l|l|l|l|l|}
\hline If you are employed please complete the following: & \multicolumn{2}{l|}{} \\
\hline Name of Company/Institution & & & \\
\hline Address of Company/Institution & \multicolumn{3}{l|}{} \\
\hline Postal Code & Telephone No. Work: & & Area dialling code: & \\
\hline Fee Account to Employer & Yes & & No & & & \\
\hline
\end{tabular}

\section{ENGLISH PROFICIENCY}

\section{APPLICABLE TO INTERNATIONAL STUDENTS ONLY}

Students applying for admission into a degree programme at the University need to demonstrate that they have obtained one of the following levels of English proficiency.

1. A pass in an examination equivalent to English at Home or First Additional language level in the NSC (National Senior Certificate) or at the Higher Grade (First or Second Language) at the South African Senior Certificate level (matriculation).

2. A pass in English language at A-level. or O-level (C-symbol or higher), or the International Baccalaureate or equivalent examination.

3. For international applicants who do not satisfy (1) or (2) above and for whom English is a foreign language:

- an overall band score of 7.0 on the International English Language Testing System (IELTS) for Post-graduate studies and 6.0 for Undergraduate studies, or

- a test score of 550 on the Test of English as a Foreign Language (TOEFL).

Scores need to be submitted with application forms.

Name of document:

\section{ADDRESS AND CONTACT DETAILS}

Postal Address:

Postal Code:
Physical address (if different from postal):

Town/City:
Contact Telephone Numbers:

Work: Code: _ No:
Home: Code: __ No:
Fax: Code:__ No:
Cell:
Email:




\section{NEXT-OF-KIN INFORMATION}

Title: Surname:

First Name (or preferred name):

$\begin{array}{llll}\text { Relationship: Father } & \text { Mother } \square & \text { Spouse } \square & \text { Brother } \square \\ & \text { Grandparent } \square \text { Child } \square & \text { Other } \square & \text { Guardian } \square\end{array}$

Postal Address:

Physical address:

Town/City:

Country (if not SA):
Contact Telephone Numbers:

Work:

Code: No:

Home:

Code: No:

Fax:

Code: No:

Cell:

Email:

\section{HIGH SCHOOL DETAILS}

Year of last school leaving certificate (equivalent to Grade 12):

Name of school certificate/diploma:

Examination No:

\section{NB: INTERNATIONAL STUDENTS TO CHECK EQUIVALENCE WITH MATRICULATION BOARD}

Type of Matriculation Exemption already held: (Please tick one)

\begin{tabular}{|l|l|l|l|l|l|}
\hline 01 & Full Exemption & & 07 & Other Seniar Certificate \\
\hline 03 & Ordinary Conditional & & 08 & NTC3/N3/NSC & \\
\hline 04 & Mature Age Exemption & & 09 & Standard 10 Practical & \\
\hline 05 & Foreign Exemption & & 10 & Other & \\
\hline 06 & Immigrants Exemption & & 11 & Discretionary Provision (Senate exemption) & \\
\hline
\end{tabular}

NOTE: The code structure has been set up by ITS in terms of government reporting requirements.

\begin{tabular}{|l|l|l|l|l|l|}
\hline \multirow{2}{*}{ SCHOOL NAME } & \multicolumn{2}{c|}{ YEAR } & \multirow{2}{*}{ Examination Authority } & \multirow{2}{*}{ Grades/Forms Passed } \\
\cline { 2 - 4 } & From & To & & \\
\hline & & & & & \\
\hline
\end{tabular}

\section{POST SCHOOL ENROLMENT}

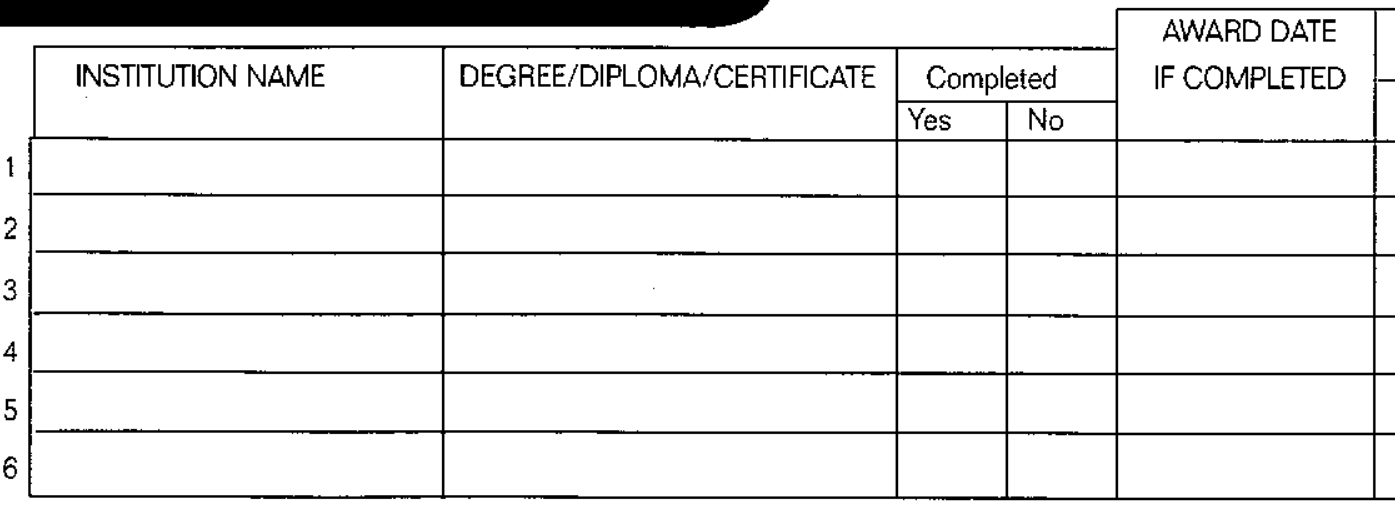

Have you ever been registered, refused entry, excluded or expelled from any university, college or technikon? If "Yes", please provide the details. If previously registered, please provide documentary proof Have you ever been refused entry to, excluded or expelled from a residence of any university, college or technikon? If "Yes", provide the details: (use separate paper if required)

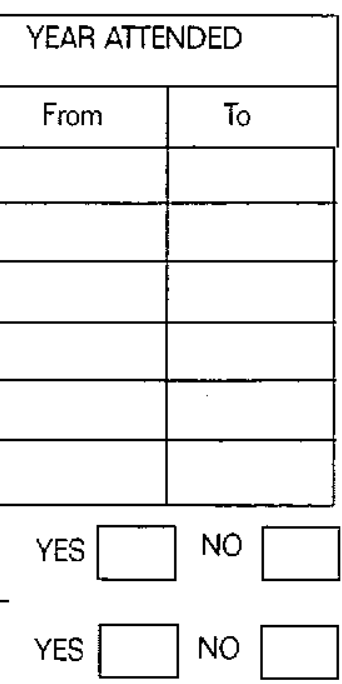




\subsection{DISABILITY INFORMATION}

The University is sensitive to the needs of students with disabilities, and will attempt to provide support where possible.

Do you have any disability, physical or otherwise, that might require support?

YES

NO If "Yes", please indicate:

Persons with a Visual Impairment

Blind

Partially sighted

Persons with a Hearing Impairment

$\longrightarrow$ Partially deaf

Mild to moderately deaf
Persons with a Physical Impairment

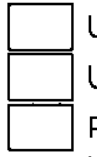

Uses a wheelchair

Uses crutches/callipers

Persons with paraplegia/quadriplegia/ hemiplegia/post-polio paralysis

Other (please specify)

\subsection{COMPULSORY HEALTH INSURANCE} FOR INTERNATIONAL STUDENTS ONLY:

(name) confirm that I will/have applied for adequate health

insurance cover while in South Africa.

Name of Health Insurance Company

Address:

Telephone No:

\section{RESIDENCE APPLICATION}

Do you wish to apply for admission to University Residence?

If yes, which Campus? Howard College Pietermaritzburg

YES

NO

If you are unsuccessful in obtaining accommodation in a University Residence. where will you stay?

Persons with Diabetes

Persons with Epilepsy

Persons with Cerebral Palsy

Persons with Intellectual/Psychiatric/

Psychological Impairment

Persons with Medical/Chronic Ailments that require support (Please specify

Other (Please specify)

\section{FUNDING OF STUDIES}

How do you propose to finance your studies?

\section{NOTE: A REGISTERED STUDENT IS RESPONSIBLE FOR PAYMENT OF ALL FEES EVEN IF FUNDED BY A SPONSOR}

\section{DECLARATION AND UNDERSTANDING}

To be completed with the assistance of Parent/Guardian where applicant is under 18 years of age (a minor).

If my application is successful and I accept the offer of a place to study at the University of KwaZulu-Natal,

1. I undertake

1.1 To comply with the procedures. rules and regulations of the University of KwaZulu-Natal.

1.2 To inform the Registrar immediately, in writing, if I change my address or if I intend cancelling my provisional acceptance.

1.3 To acquaint myself with all the rules and general regulations that relate to the degree for which $I$ am applying.

1.4 To make alternate arrangements for accommodation should the University accept me for the degree and cannot offer me accommodation.

2. We hereby accept liability for the payment of all tuition fees or other fees which may be charged by the University as a result of my/his/her studies at the University.

3. I am aware that my enrolment is valid only if it complies with the regulations of the degree concerned, notwithstanding the acceptance of this application by the University.

4. We accept the responsibility of submitting all documents required by the University before the stipulated due dates.

5. I declare

5.1 That I make this application and give the declarations and understandings with the knowledge and consent of my parent/guardian/employer.

5.2 I warrant that the information contained herein is true and correct and the University shall be entitled to declare the contract void and cancel my registration if I have made any misrepresentation or omission on this application.

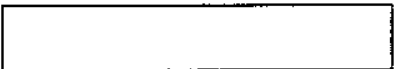

Signature of Student

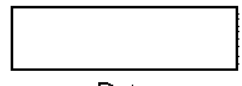

Date

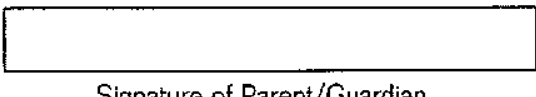

Signature of Parent/Guardian

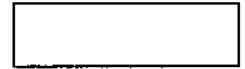

Date

SURETYSHIP To be completed with the assistance of Parent/Guardian where applicant is under 18 years of age (a minor). I, the undersigned lawful parent/guardian of the applicant, do hereby bind myself to the University of KwaZulu-Natal as surety in solidium and co-principal debtor with the above-named applicant for the due payment of all fees and other charges due and payable to the University of KwaZulu-Natal in terms of the relevant applicable annual schedule of fees. The surety will operate as a continuing covering suretyship. I agree that I will not be released from liability under this suretyship in any circumstances what ever, except with the University of KwaZulu-Natal's written consent and in particular, I shall not be released by reason of the fact that the aggregate amount owed to you by the applicant may fluctuate and may at times be nil.

Please print full name of Surety/Parent/Guardian: Identity no.

Address:

Which will be my domicilium citandi et executandi (permanent residential address) for all purposes under this document which means that I will accept service of all notices, documents and legal proceedings against me. In the event of my changing this address I agree to inform the Student Debtors Section of the Finance Department of the University of KwaZulu-Natal of any change in my address. 


\section{CHECKLIST}

Please ensure that the following relevant documents are enclosed with this application

- Have you indicated your choice of degree/diploma and campus?

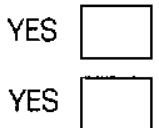

- Have you enclosed the non-refundable application fee?

YES

English translation

- Academic Record (if studied previously)

- Degree Certificate (if studied previoushy) if applicable

- Senior Certificate/Matric Certificate/O/A Levels or relevant school leaving qualification/certificate/SAQA Certificate

-. Residency/Temp Residency Permits

- English Proficiency proof

Compulsory for international

- Medical Insurance Info students only

- Have you completed the residence section $\{10\}$ if applicable?

Have you filled in the application form in full?
YES

YES

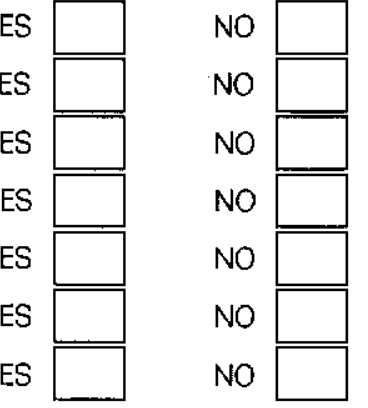

YES

YES
NO

NO

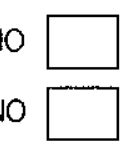

NO

NO

$\mathrm{NO}$

\section{FOR OFFICIAL USE}

This section to be completed by the HEAD OF DISCIPLINE in which you intend to register

DISCIPLINE OF STUDY (not dissertation/thesis title): For Research Masters and doctoral candidates

COURSE WORK REQUIRED: For Course Work Masters only:

IS ADMISSION TO STATUS REQUIRED? Yes

No

If 'YES, to which degree?

ADMISSIONS UNDER SPECIAL CONDITIONS

NOTE: Where a candidate holds an appropriate equivalent degree from another University Faculty, admission under special conditions will be a technicality and a statement to this effect is all that is required here. A detailed motivation MUST accompany this form for all special condition cases which are not of a routine 'technical' nature.

Please attach a full CV in the area of specialisation and supporting documentation.

ADDITIONAL COMMENTS:

\section{SUPERVISOR}

CO-SUPERVISOR

\author{
Name:
}

Name:
School/Programme

School/Programme

I have considered
(a) the viability, nature and extent of the project
(b) the suitability of the candidate
(c) the availability and suitability of supervision
(d) the nature and extent of the necessary resources and I recommend that the candidate be accepted for the degree.

SIGNATURE OF HEAD OF DISCIPLINE/PROGRAMME: DATE:

PROVISIONALLY APPROVED BY HEAD OF SCHOOL: DATE:

PROVISIONALLY APPROVED BY DEAN: DATE:

Considered by:

Approved by: 


\section{University of KwaZulu-Natal}

\section{APPLICATION FOR EMMA SMITH OVERSEAS SCHOLARSHIP: 2009 \\ (Reference: 30/33/5)}

SECTION A: PERSONAL

\begin{tabular}{|l|l|}
\hline SURNAME & \\
\hline FIRST NAMES & \\
\hline TITLE & \\
\hline POSTAL ADDRESS & \\
\hline & $\begin{array}{l}\text { RESIDENCE : } \\
\text { BUSINESS } \\
\text { CELL }\end{array}$ \\
\hline E-MAIL ADDRESS
\end{tabular}

SECTION B: CURRENT AND PREVIOUS RESIDENTIAL ADDRESSES

Please list for a period of three years up to present date

\begin{tabular}{|l|l|}
\hline PERIOD & ADDRESS \\
\hline & \\
\hline & \\
\hline & \\
\hline
\end{tabular}


SECTION C: TERTIARY EDUCATIONAL QUALIFICATIONS

\begin{tabular}{|c|c|c|c|c|c|}
\hline $\begin{array}{c}\text { INSTITUTION } \\
\text { ATTENDED }\end{array}$ & $\begin{array}{c}\text { STUDENT } \\
\text { NUMBER }\end{array}$ & $\begin{array}{c}\text { COURSE OF } \\
\text { STUDY }\end{array}$ & DURATION & $\begin{array}{c}\text { QUALIFICATION } \\
\text { GAINED }\end{array}$ & YEAR \\
\hline & & & & & \\
\hline & & & & & \\
\hline & & & & & \\
\hline
\end{tabular}

\section{SECTION D: PROPOSED STUDIES/RESEARCH}

Give details of proposed postgraduate study/research:- -

\begin{tabular}{|l|l|l|l|}
\hline INSTITUTION & QUALIFICATION & COUNTRY & YEARS OF STUDY \\
\hline & & & \\
\hline & & & \\
\hline & & & \\
\hline
\end{tabular}

RESEARCH PROPOSAL (Applicants may use a separate sheet for their proposal if this space is insufficient)

\begin{tabular}{|l|}
\hline \\
\hline \\
\hline \\
\hline \\
\hline \\
\hline \\
\hline
\end{tabular}


SECTION E: APPLICANT'S INCOME AND EXPENSES

\begin{tabular}{|l|l|l|l|}
\hline $\begin{array}{l}\text { CREDIT (List here all sources of } \\
\text { Income, ie, your plans to meet } \\
\text { Expenses) }\end{array}$ & $\begin{array}{l}\text { CREDIT } \\
\text { RANDS }\end{array}$ & $\begin{array}{l}\text { DEBIT (List here anticipated } \\
\text { expenses) }\end{array}$ & $\begin{array}{l}\text { DEBIT } \\
\text { RANDS }\end{array}$ \\
\hline Parental contribution/allowance & & Accommodation & \\
\hline Holiday employment & & Meals & \\
\hline Part-time employment & & University Tuition & \\
\hline Salary & Books & \\
\hline Savings & Transport & \\
\hline Bursaries/Loans/Scholarships & & Living expenses & \\
\hline & & Other (Please specify) & \\
\hline TOTAL (R) & & TOTAL (R) & \\
\hline
\end{tabular}

SECTION F: ADDITIONAL INFORMATION

(Enclose documentary proof, if applicable)

I wish the following additional information (if any) to be taken into consideration):

\begin{tabular}{|l|}
\hline \\
\hline \\
\hline \\
\hline \\
\hline \\
\hline \\
\hline
\end{tabular}




\section{NOTE:}

1. This application must be accompanied by a full transcript of the academic record.

2. Academic reports from two referees must accompany this application.

3. A full curriculum vitae (CV) must also accompany this application.

4. Please advise if you have made contact with any foreign host university and if so, kindly provide details.

5. Please advise as to why you have applied for this scholarship.

\section{SECTION G: AFFIDAVIT}

I do solemnly declare and affirm that the particulars above are to the best of my knowledge and belief true and correct and that the financial information set forth truly and correctly discloses my income, nothing excepted.

I understand that should any relevant information be omitted or found to be incorrect, disciplinary action will be taken by the University authorities, which could result in the invalidation of the award.

DATE :

APPLICANTS SIGNATURE :

SWORN BEFORE ME AT of....... this. day

by the deponent, who acknowledges that she fully understands the contents of this Affidavit. 
TO BE COMPLETED IN INK AND BLOCK CAPITALS (PLEASE PRESS FIRMLY).

THE USE OF CORRECTING FLUID WILL INVALIDATE THIS APPOINTMENT.

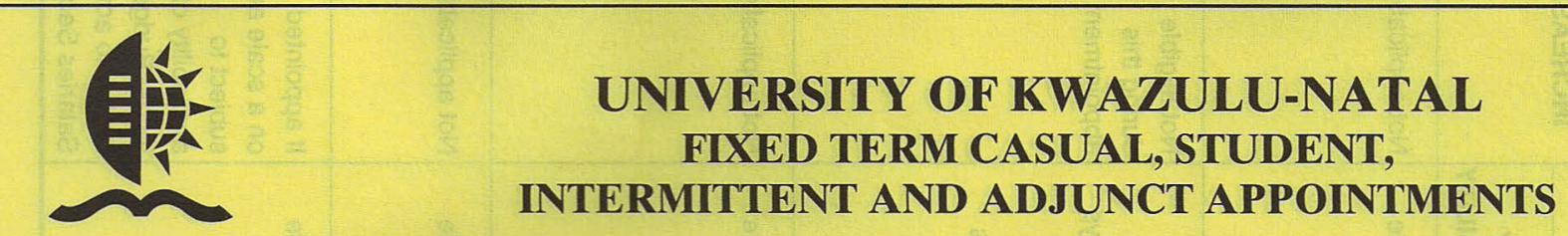

A. APPOINTMENT DETAILS:

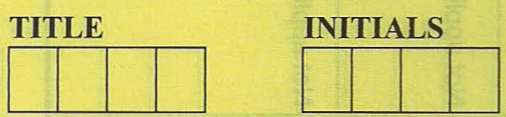

SURNAME

PROPOSED DESIGNATION

DEPT / UNIT / PROGRAMME

TEL. EXT

SCHOOL

FACULTY / DIVISION

CAMPUS

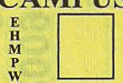

LINE MANAGER OF APPOINTEE

\begin{tabular}{|l|l|l}
\hline NAME & STAFF No. & TEL. Ext. \\
\hline
\end{tabular}

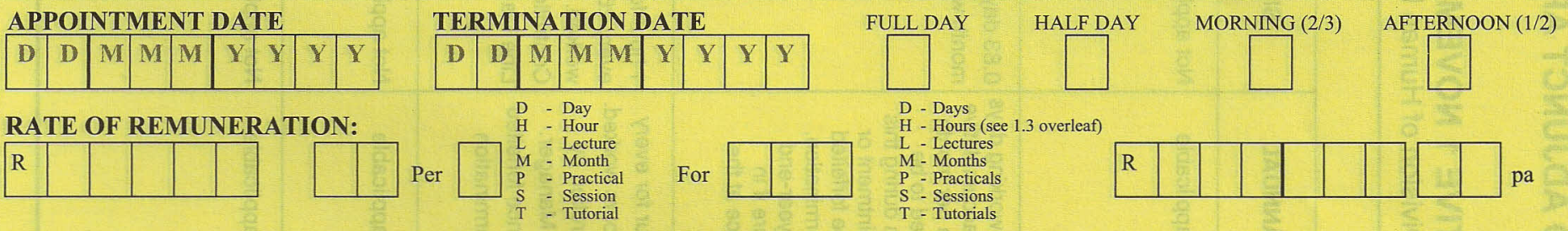

MEDICAL AID (if applicable)

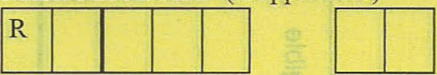

Y/N $\square$

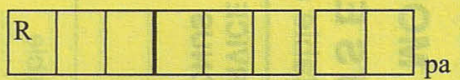

STATUTORY COSTS $(0,25 \%$ of rate of remuneration)

\begin{tabular}{|l|l|l|l|l|l|}
\hline $\mathrm{R}$ & & & & & \\
\hline
\end{tabular}

METHOD OF PAYMENT:

(Please tick appropriate box)

PAYROLL

CLAIM

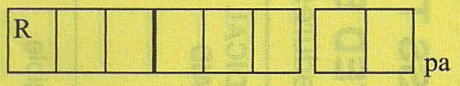

IF ON PAYROLL TICK MONTHS OF PAYMENT

\begin{tabular}{|l|l|l|l|l|l|l|l|l|l|l|l|l|l|l|l|l|l|l|l|l|l|l|l|l|l|l}
\hline JAN & FEB & MAR & APR & MAY & JUN & JUL & AUG & SEP & OCT & NOV & DEC & R & & & & \\
\hline
\end{tabular}

B. ALLOCATION OF COSTS:

POST/FUND DESCRIPTION

POST NO.

DEPT. NO.

COST CENTRE ACC. CATEGORY

\section{IMPORTANT INFORMATION:}

1. This application must be submitted in full to Human Resources before the appointee assumes duty. Forms received after the 1 st working day of the month will be processed the following month. Incomplete forms will be returned.

2. In the case of externally funded appointments, such funding MUST be cleared by Finance BEFORE submission to Human Resources.

\begin{tabular}{|l|l|}
\hline HEAD: PROGRAMME/DEPT/UNIT/SECTION & \\
GRANTHOLDER (for external Funds) & \\
\hline HEAD OF SCHOOL/DEPARTMENT/SECTION & \\
$\begin{array}{l}\text { I........................................................ hereby confirm that the University } \\
\text { Recruitment and Selection, Employment Equity and Nepotism policies have } \\
\text { been adhered to and agree to advise HR immediately should this contract terminate } \\
\text { prior to the above termination date. }\end{array}$ & \\
\hline EXECUTIVE MEMBER & \\
\hline $\begin{array}{l}\text { DEAN/DIVISIONAL HEAD } \\
\text { (Where there is no Dean a second Authorised Signatory may be required) }\end{array}$ & \\
\hline $\begin{array}{l}\text { FINANCE OFFICER } \\
\text { (External Funds \& Code to be approved) }\end{array}$ & \\
\hline $\begin{array}{l}\text { HUMAN RESOURCES OFFICER: } \\
\text { NAME: }\end{array}$ & \\
\hline
\end{tabular}

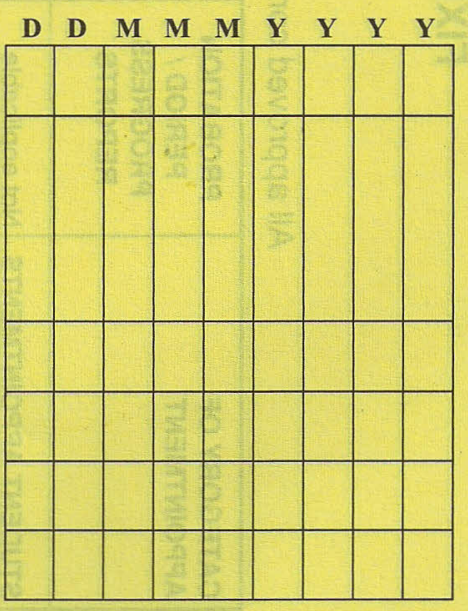




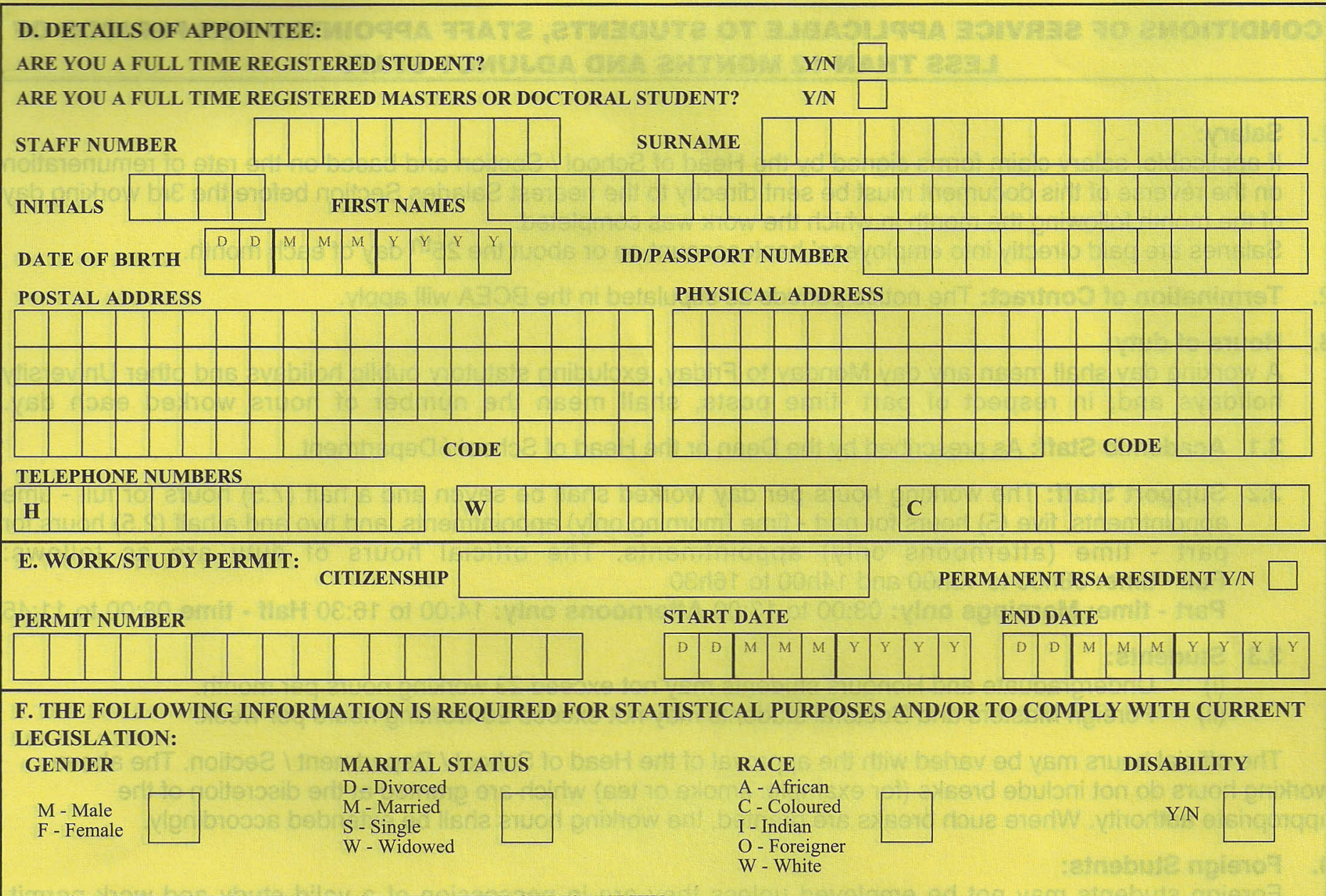

IF ANSWER TO DISABILITY IS YES, STATE NATURE OF DISABILITY

Are you in a relationship with or related to a staff member or student of this University?

If yes, kindly state his/her full name and department

Have you previously been employed by the University of Natal, Durban-Westville, or KwaZulu-Natal? Y/N $\square$

If yes, please provide details on a separate page, including reasons for termination of service (e.g. end of contract, resignation, etc.). The permission of the University Executive Management is required to validate this contract if you have previously been classified as a persona non grata due to nature of your termination of service.

G. BANKING DETAILS:

\begin{tabular}{|l|l|l|l|}
\hline NAME OF BANK & & \\
\hline NAME OF BRANCH & & \\
\hline $\begin{array}{l}\text { TYPE OF ACCOUNT } \\
\text { (PLEASE TICK) }\end{array}$ & CURR. & SAV. & TRANS. \\
\hline
\end{tabular}

BRANCH NUMBER

ACCOUNT NUMBER

\section{H. TAX DETAILS:}

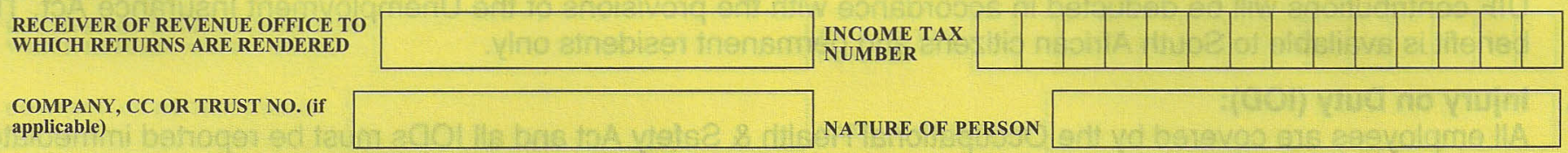

DECLARATION OF OTHER EARNINGS AND EMPLOYMENT FOR TAX PURPOSES (Please tick applicable box)

I hereby declare that:

1. I do have other employment external to the university (25\% PAYE DEDUCTED)

2. I DO NOT have any other employment (IRP10 Tax Tables)

I. THIS APPOINTMENT IS SUBJECT TO THE APPLICABLE TERMS AND CONDITIONS OF SERVICE PRINTED ON THE REVERSE SIDE OF THIS DOCUMENT AND FINAL APPROVAL BY HUMAN RESOURCES.

J. DECLARATION \& ACKNOWLEDGEMENT: I declare that information given in this document is true and correct/ there is no change to details previously provided in respect of sections $D$ to $H$.

I warrant that:

1) I do not have a criminal record and that I know of no reason why I should not be employed in this position.

2) I have read, understood and accept all the conditions of this appointment and sign same freely and voluntarily.

$$
\text { SIGNATURE }
$$$$
\text { NAME (please print) }
$$

\section{APPOINTEE:}




\section{Appendix 2: List of interviewees}

\begin{tabular}{|l|l|r|}
\hline Name & Department & Date of Interview \\
\hline Reena Budree & Equity Manager- University of Natal & $14-F e b-02$ \\
\hline Jabulani Fihlela & Risk Management Service & 11-Aug-09 \\
\hline Nirmala Gopal & $\begin{array}{l}\text { National Tertiary Education Staff Union } \\
\text { - NTESU }\end{array}$ & 17-Jul-09 \\
\hline Jay Govender & HR - Diversity and Employment Equity & 13-Jul-09 \\
\hline Alfred Kebeje & Faculty of Humanities & 26-Oct-09 \\
\hline Hope Mashilo & Equity Manager- M.L. Sultan Technikon & 15-Feb-02 \\
\hline Futhi Mbanjwa & $\begin{array}{l}\text { Equity Officer- University of Durban- } \\
\text { Westville }\end{array}$ \\
\hline Lizwi Mhlane & Equity Manager - Technikon Natal & 21-Feb-02 \\
\hline Richard Morrison & Financial Aid & 13-Jul-09 \\
\hline Karan Naidoo & Financial Aid - Scholarships & 2-Sep-09 \\
\hline Willem Sturm & Dean Medical School UKZN & 4-Sept-09 \\
\hline Ronal Thakurpersad & Faculty Office - Engineering & 1-Jun-09 \\
\hline Anita van Soelen & Central Applications Office - admissions & \\
\hline Trevor Wills & & Dean of Students \\
\hline
\end{tabular}




\section{Appendix 3: Interview schedule (2009)}

1. What is the purpose of classification at different sites?

o What are the reason and uses for classification?

o How is this information obtained?

2. What are the criteria for classification?

3. In which situations is classification deemed necessary (examples)?

4. Who is responsible for classification?

5. Who is subject to classification?

6. What are the process/processes of classification within different departments/sites?

7. Is classification determined by policy?

o If yes, what policy is used?

8. How do those who are classified respond to classification/their classification?

9. Are there any challenges faced in classifying people according to race (here the perceived effects of classification will be probed)?

10. How are the challenges addressed, if at all?

11. Are there alternative options for classification towards similar ends, other than race? o If yes, what are the alternatives? 
Appendix 4: UKZN Equity Plan for the Division of Student Services 2006 (Extract) 


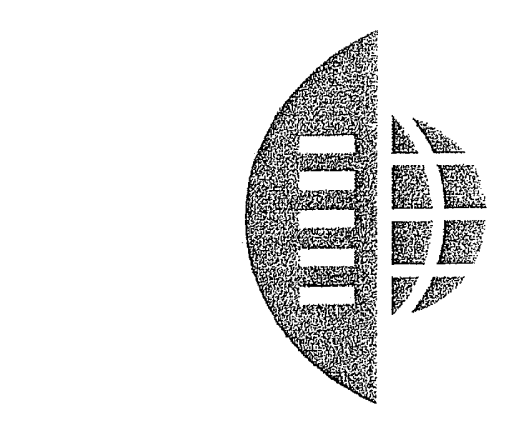

\author{
UNIVERSITY OF \\ KWAZULU-NATAL
}

\title{
Equity Plan
}

\author{
for the
}

\section{Division of Student Services} 2006

Chairperson (DEEC):

Executive Dean (Students): 


\subsection{Overview of Staff Profile}

\subsubsection{Gender}

According to divisional data the following was found:

- Women make up 61\% of staff in the Division (Table 5(b)) which is a slight increase over 2004 levels. However, there is still a skewing of women employees towards Peromnes categories lower than 9 . Men are clearly under represented at a divisional level.

- When comparisons with the national and regional benchmarks are made, Indian, and White employees are still over represented, but only marginally so in the case of Coloured staff (and Coloured male staff are under represented).

- In terms of the racial breakdown, African women are particularly under represented at the higher Peromnes levels (>9).

\subsubsection{Race}

In terms of race the following was found:

- $53.5 \%$ of the overall staff complement in the Division is African followed by $28.7 \%$ Indian, $14.2 \%$ White and only $3.5 \%$ Coloured (Table 5). This shows only slight changes from figures reported in 2004 and 2005, with a slight increase in the proportion of African staff and decrease in Indian staff (32\% to $28.7 \%$ ).

- African staff are still largely concentrated within the lower Peromnes levels, but recent appointments have been made at the upper levels.

- While only $14 \%$ of the staff are white, a higher proportion of these staff are found in the middle and upper Peromnes levels than is the case with other groups.

\subsubsection{Disability}

There is a very noticeable lack of representation of staff with disabilities within the Division of Student Services. Statistics indicate that there are 2 out of 282 employees $(0.7 \%)$.

\subsection{Recommendations}

- The Divisional Equity Plan needs to address the under-representation of African women at the more senior management level.

- The representation of Coloured staff at senior levels must be emphasized in making appointments.

- The employment of people with disabilities needs to be significantly improved, and advertising must stress the University's commitment to employing people with disabilities. Each opportunity which arises in Student Services must be assessed with the appointment of staff with disabilities in mind, taking the inherent requirements of the posts into account and the work environment implications (eg access, equipment requirements and so on).

- Generally the overall African staff representation needs to be improved to bring the Division closer to the benchmarks used (particularly the regional figures for KZN).

- The internal promotion of designated groups to more senior management levels needs to emphasized. 